\title{
Calculating Contained Firing Facility (CFF) Explosive Firing Zones
}

\author{
J. W. Lyle
}

October 20, 1998

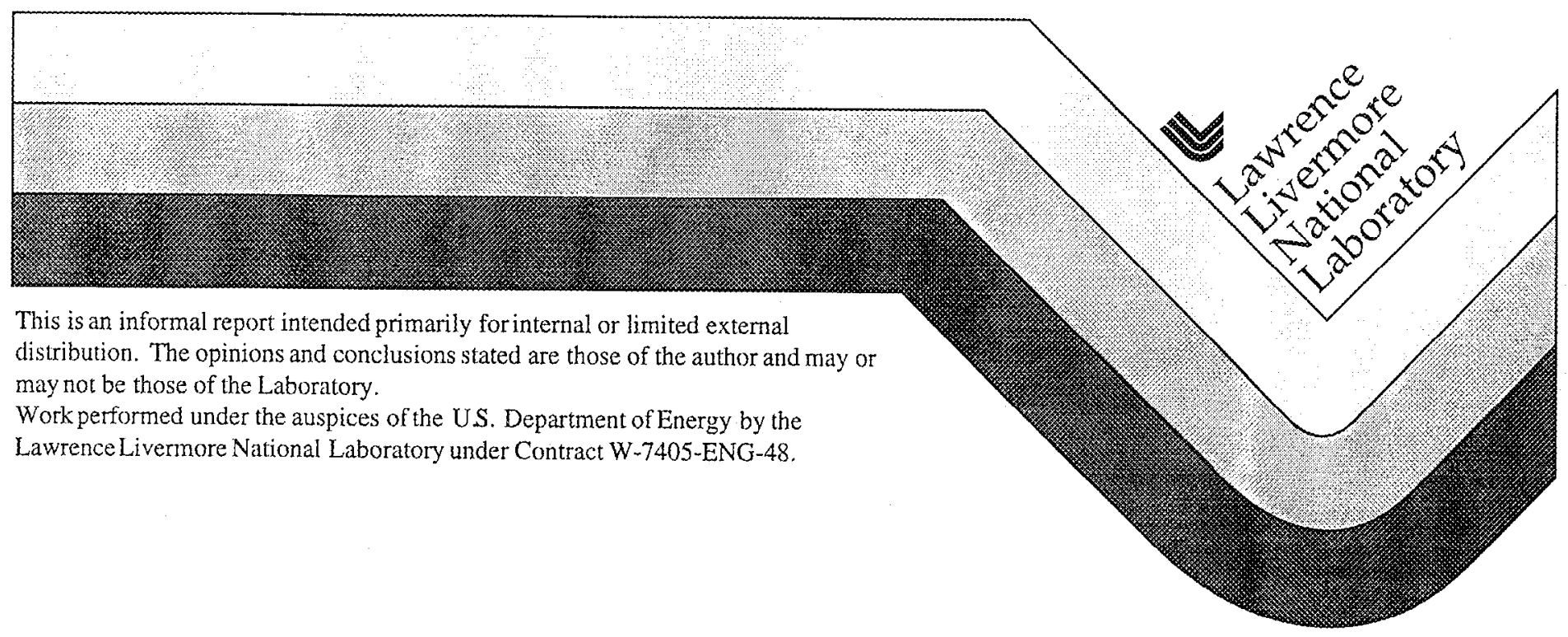




\section{DISCLAIMER}

This document was prepared as an account of work sponsored by an agency of the United States Government. Neither the United States Government nor the University of California nor any of their employees, makes any warranty, express or implied, or assumes any legal liability or responsibility for the accuracy, completeness, or usefulness of any information, apparatus, product, or process disclosed, or represents that its use would not infringe privately owned rights. Reference herein to any specific commercial product, process, or service by trade rame, trademark, manufacturer, or otherwise, does not necessarily constitute or imply its endorsement, recommendation, or favoring by the United States Government or the University of California. The views and opinions of authors expressed herein do not necessarily state or reflect those of the United States Government or the University of California, and shall not be used for advertising or product endorsement purposes.

This report has been reproduced directly from the best available copy.

Available to DOE and DOE contractors from the Office of Scientific and Technical Information

P.O. Box 62, Oak Ridge, TN 37831

Prices available from (423) 576-8401

Avallable to the public from the National Technical Information Service

U.S. Department of Commerce

5285 Port Royal Rd.,

Springfield, VA 22161 


\title{
CALCULATING CONTAINED FIRING FACHLITY (CFF) EXPLOSIVE FIRING ZONES
}

\author{
J. W. Lyle *
}

October 20, 1998

1. INTRODUCTION

The University of Califormia awarded LLNL contract No. B345381 for the design of the facility to Parsons Infrastructure \& Technology, Inc., of Pasadena, California. The Laboratory specified that the firing chamber be able to withstand repeated firings of $60 \mathrm{Kg}$ of explosive located in the center of the chamber, 4 feet above the floor, and repeated firings of $35 \mathrm{Kg}$ of explosive at the same height and located anywhere within 2 feet of the edge of a region on the floor called the anvil. Other requirements were that the chamber be able to accommodate the penetrations of the existing bullnose of the Bunker 801 flash X-ray machine and the roof of the underground camera room.

These requirements and provisions for blast-resistant doors formed the essential basis for the design. The design efforts resulted in a steel-reinforced concrete structure measuring (on the inside) $55 \times 51$ feet by 30 feet high. The walls and ceiling are to be approximately 6 feet thick. Because the $60-\mathrm{Kg}$ charge is not located in the geometric center of the volume and a $35 \sim \mathrm{Kg}$ charge could be located anywhere in a prescribed area, there will be different dynamic pressures and impulses on the various walls, floor, and ceiling, depending upon the weights and locations of the charges.

The detailed calculations and specifications to achieve the design criteria were performed by Parsons and are included in Reference 1.

Reference 2, Structures to Resist the Effects of Accidental Explosions (TM5-1300), is the primary design manual for structures of this type. It includes an analysis technique for the calculation of blast loadings within a cubicle or containment-type structure. Parsons used the TM5-1300 methods to calculate the loadings on the various firing chamber surfaces for the design criteria explosive weights and locations. At LLNL the same methods were then used to determine the firing zones for other weights and elevations that would give the same or lesser loadings. Although very laborious, a hand calculation of the different variables is possible, and an example is given in Appendix C. Fortunately, a code called "SHOCK" is available to perform these calculations rapidly, and the code runs on a personal computer. The original code was developed by the firm Amman and Whitney, which they called "Paimpres"; this was modified to its present form by the U.S. Naval Civil Engineering Laboratory. Parsons used the SHOCK code extensively, as well as several single- and multiple-degree-of-freedom codes, which were provided by the U.S. Corps of Engineers. In addition, Parsons based their analysis/design on procedures stipulated in the publication DOE/TIC-11268, A Manual for the Prediction of Blast and Fragment Loadings on Structures.

Loadings on structures in Reference 2 and in calculations performed with the SHOCK code are based on weights of explosives in pounds of TNT equivalent. The equivalency of an explosive (for its blast effects on structures) is calculated by the ratio of its heat to detonation to that of TNT. We intend to use the explosive C-4 for testing the response of the firing chamber. Various values of the ratio for $\mathrm{C}-4$ are available: Reference 2 lists numbers leading to a ratio of 1.15 , while 1.13 is the ratio calculated from numbers given in the LLNL Explosives Handbook (Reference 3). Parsons used a ratio value of 1.3 for generic high explosive-to-TNT equivalency. For design purposes, Reference 2 recommends a 20 percent increase in explosive weight. Parsons adopted this recommendation. Therefore, for calculational purposes, $60 \mathrm{Kg}$ of generic high explosive was taken to be equivalent to 206.3 pounds of TNT. That is, $60 \mathrm{Kg} \times 2.204 \mathrm{lb} / \mathrm{Kg} \times 1.3 \times 1.2=206.3 \mathrm{lb}(\mathrm{TNT})$. 
In section 2-14.2.1. of Reference 2, it is written:

An approximate method for the calculation of the internal shock pressures has been developed using theoretical procedures based on semi-empirical blast data and on the results of response tests on slabs. The calculated average shock pressures have been compared with those obtained from the results of tests of a scale-model steel cubicle and have shown good agreement for a wide range of cubicle configurations. This method consists of the determination of the peak pressures and impulses acting at various points of each interior surface and then integrating to obtain the total shock load. In order to simplify the calculation of the response of a protective structure wall to these applied loads, the peak pressures and total impulses are assumed to be uniformly distributed on the surface. The peak averagc pressure and the total average impulse are given for any wall surface. The actual distribution of the blast loads is highly irregular, because of the multiple reflections and time phasing and results in localized high shear stresses in the element. The use of the average blast loads, when designing, is predicated on the ability of the element to transfer these localized loads to regions of lower stress. Reinforced concrete with properly designed shear reinforcement and steel plates exhibit this characteristic.

The procedure for the determination of the shock loads was programmed for solutions on a digital computer. In Reference 2, the resuits are presented for the average peak reflected pressures on 48 figures and for the average scaled unit impulse on 48 more figures. Fortunately, the text and figures of TM5-1300 are available as computer software which includes the means to read the curves. In this way it is easy to obtain peak reflected pressure, impulse, pulse lenglh, and olher variables as a function of the scaled distance $\left(Z=\frac{R}{W^{1 / 3}}\right.$ ). In this expression, $R$ is the distance from charge center to the surface in question and $W$ is the weight of explosive in equivalent TNT pounds. The CFF firing chamber geometry is included in the range of the plotted variables so that extrapolation was not necessary, but interpolation between as many as six curves was required to fit some charge locations. The use of the SHOCK code greatly assists this process. Again from Refcrence 2: "The wall (if any) parallel and opposite to the surface in question has a negligible contribution to the shock loads for the range of parameters used and was therefore not considered."

The analysis leads to the conclusion that each of the chamber surbes can be characterized by the peak pressure it would experience. For the floor. it is obvious that $\mathrm{se}$ maximum charge at 4 feet elevation yields the highest pressure, which at a point directly benein the charge would be approximately $15,541 \mathrm{psi}$. The same charge gives the highest pressure on the ceiling, approximately 78 psi. The various locations of a $120.3-1 b$ charge two feet inside the anvil edge yield the highest pressures on the walls according to the following table. 
TABLE 1

SHOCK CODE CALCULATIONS OF PRESSURE ON THE VARIOUS SURFACES

Explosive Charges at 4 -foot elevation

\begin{tabular}{|c|c|c|c|}
\hline Surface & $\begin{array}{c}\text { Pressure at Point } \\
\text { Nearest Charge } \\
\text { psi }\end{array}$ & $\begin{array}{c}\text { Maximum Average } \\
\text { Pressure on Entire } \\
\text { Surface } \\
\text { psi }\end{array}$ & \multicolumn{1}{c|}{ Caused by } \\
\hline Floor & $15,541.3$ & 400.9 & $206.3 \mathrm{lb}$ TNT, centered \\
\hline Ceiling & 163.5 & 78 & $206.3 \mathrm{lb}$ TNT, centered \\
\hline W wall & $2,408.7$ & 234.7 & $\begin{array}{l}120.3 \mathrm{lb} \text { TNT, } 8.53 \text { feet from wall as if no } \\
\text { bullnose were present) }\end{array}$ \\
\hline E wall & 664.2 & 126.9 & $120.3 \mathrm{lb}$ TNT, 13 feet from wall \\
\hline N wall & $2,602.9$ & 209 & $120.3 \mathrm{lb}$ TNT, at NE corner of the anvil \\
\hline S wall & 229.7 & 80 & $120.3 \mathrm{lb} \mathrm{TNT}$. centered 19.7 feet from S wall \\
\hline
\end{tabular}

Initially, a series of calculations was performed for the 4-foot elevation to determine where $60 \mathrm{Kg}$ of explosive could be placed so that the design criteria pressures on the walls would not be exceeded. The area on the anvil for the location of $35-\mathrm{Kg}$ charges was taken as given. The analysis was then extended at $5-\mathrm{Kg}$ intervals $t o$ fill in the space on the anvil between $35 \mathrm{Kg}$ and $60 \mathrm{Kg}$. The same analysis also located the $1-\mathrm{Kg}$ line. Near the north wall there is a trench in the floor, so we thought it prudent to move the $1 \mathrm{-Kg}$ line a foot or so inwards to avoid bending the trench cover plates. Intermediate explosive weights between the north $1-\mathrm{Kg}$ line and the $35-\mathrm{Kg}$ line on the anvil were placed linearly between these two boundaries as an expedient even though it is recognized that the analysis is non-linear. In order to minimize stresses on the camera room roof, the area south of the $35-\mathrm{Kg}$ line is limited to $1.5 \mathrm{Kg}$. After discussions with Larry Simmons, it was agreed that the maximum distributed explosive charge on top of the underground camera room would be $1.5 \mathrm{~kg}$. We derived this quantity by considering that, at most, 10 mirror pads would be used on a single shot. The pad's present explosive weight is 75 grams, but anticipated future design modifications may call for up to 150 grams each.

The SHOCK code features a reduced area calculation. This scheme was used to calculate the pressures and the impulse on the inner door frame of the equipment blast door as if the door were there rather than its actual location at the outer wall, 6 feet further away from the explosive. The results were then used to adjust the map profiles so that the design criteria of pressure and impulse at the virtual door would not be exceeded for any explosive weight or location.

The explosive weights at elevations less than 4 feet were calculated so that the pressures on the floor would not exceed $15,541.3 \mathrm{psi}$. The explosive weights at elevations greater than 4 feet were calculated so that the pressure on the ceiling would not exceed 78 psi. 


\section{CONCLUSIONS}

The curves in Appendix A are meant to be used by ramrods, physicists, engineers, and bunker personnel for the safe placement of explosives at the facility. The objective is to maintain a minimum safety factor of 1.7 to the elastic limit for the most heavily stressed chamber element. It is important to point out that the curves are based solely on calculations. The iiring chamber will be fitted with gauges to measure strain. As testing and operating experience are accumulated, it is quite likely that the map profiles will be adjusted. In addition, deviations from these maps are possible with appropriate analysis, approval, and planning and through the use of blast attenuation and mitigation measures.

The most heavily stressed element in the firing chamber will be the floor. Various configurations of attenuating materials have been tested that minimize blast damage to the floors of explosive testing chambers. Some examples can be found in Reference 4. Additional experimental studies are now being planned as the basis for the design of an attenuating system for use in the firing chamber. Our intention is to use such a system until experience shows that it may not be necessary. 


\section{REFERENCES}

1. Site 300, Contained Firing Facility, Final Structural Chamber Calculations, LLNL Contract No. B345381, Parsons Job No. 732925, May 29, 1998.

2. Departments of the Army, Navy, and Air Force, Structures to Resist the Effects of Accidental Explosions, Army TM 5-1300, Headquarters, Washington, D.C., 19 November 1990.

3. B. M. Dobratz and P. C. Crawford, LLNL Explosives Handbook, Properties of Chemical Explosives and Explosive Simulants, Lawrence Livermore National Laboratory, Livermore, California, UCRL52997 Change 2, January 31, 1985.

4. J. W. Pastrnak, C. F. Baker, and L. F. Simmons, Quarter-Scale Close-in Blast-Loading Experiments in Support of the Planned Contained Firing Facility, Lawrence Livermore National Laboratory, Livermore, California, UCRL-1C-116822, July 27, 1994. 
Explosive firing zone maps are given for six elevations $1,2,3,3.5,4,8$, and 12 feet above the floor. The region to the south of the $35 \mathrm{Kg}$ line, over the camera room roof, is limited to a total distributed explosive weight of $1.5 \mathrm{Kg}$. This will accommodate 10 optical turning mirror explosive pads of 150 grams each. 


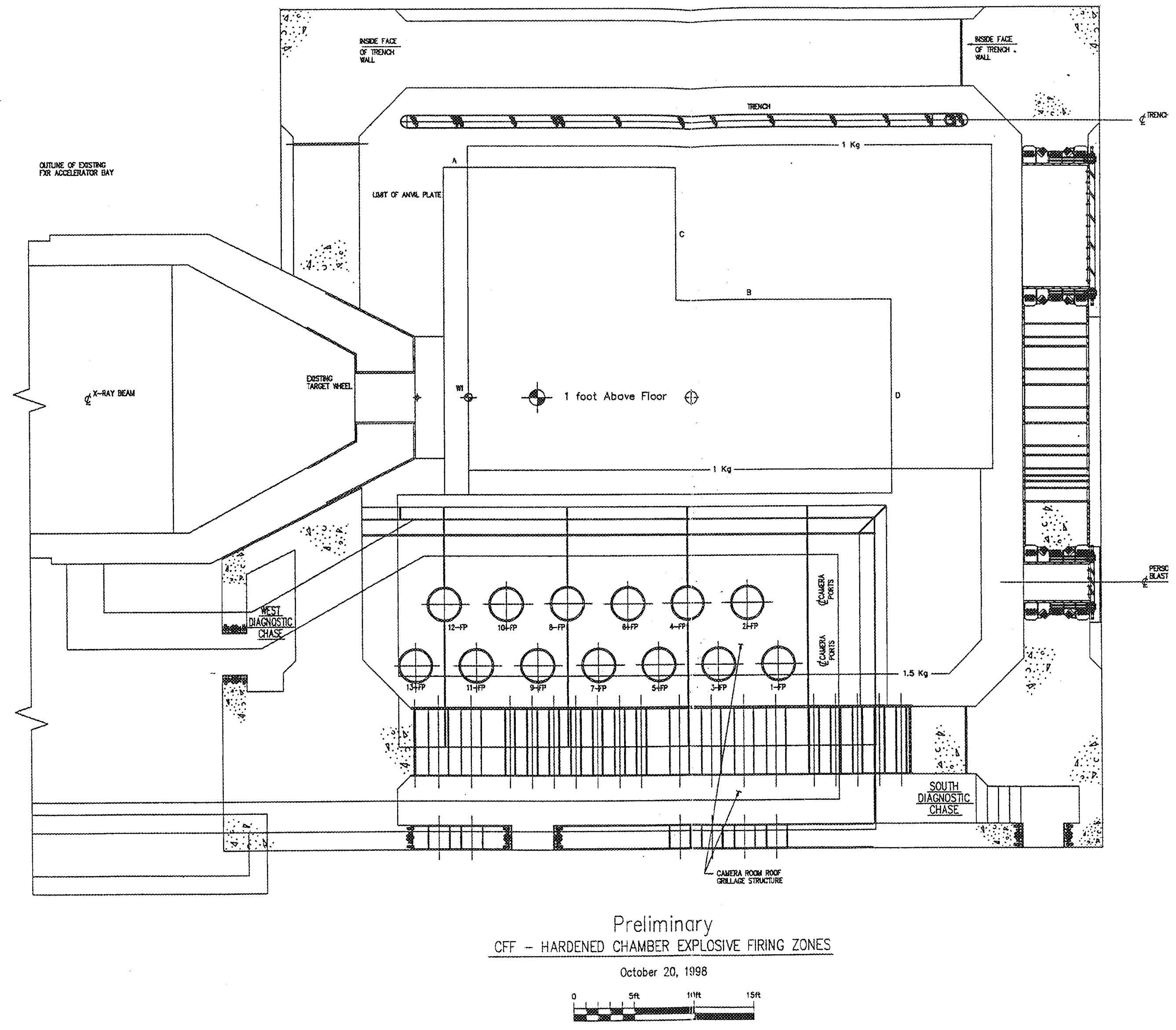




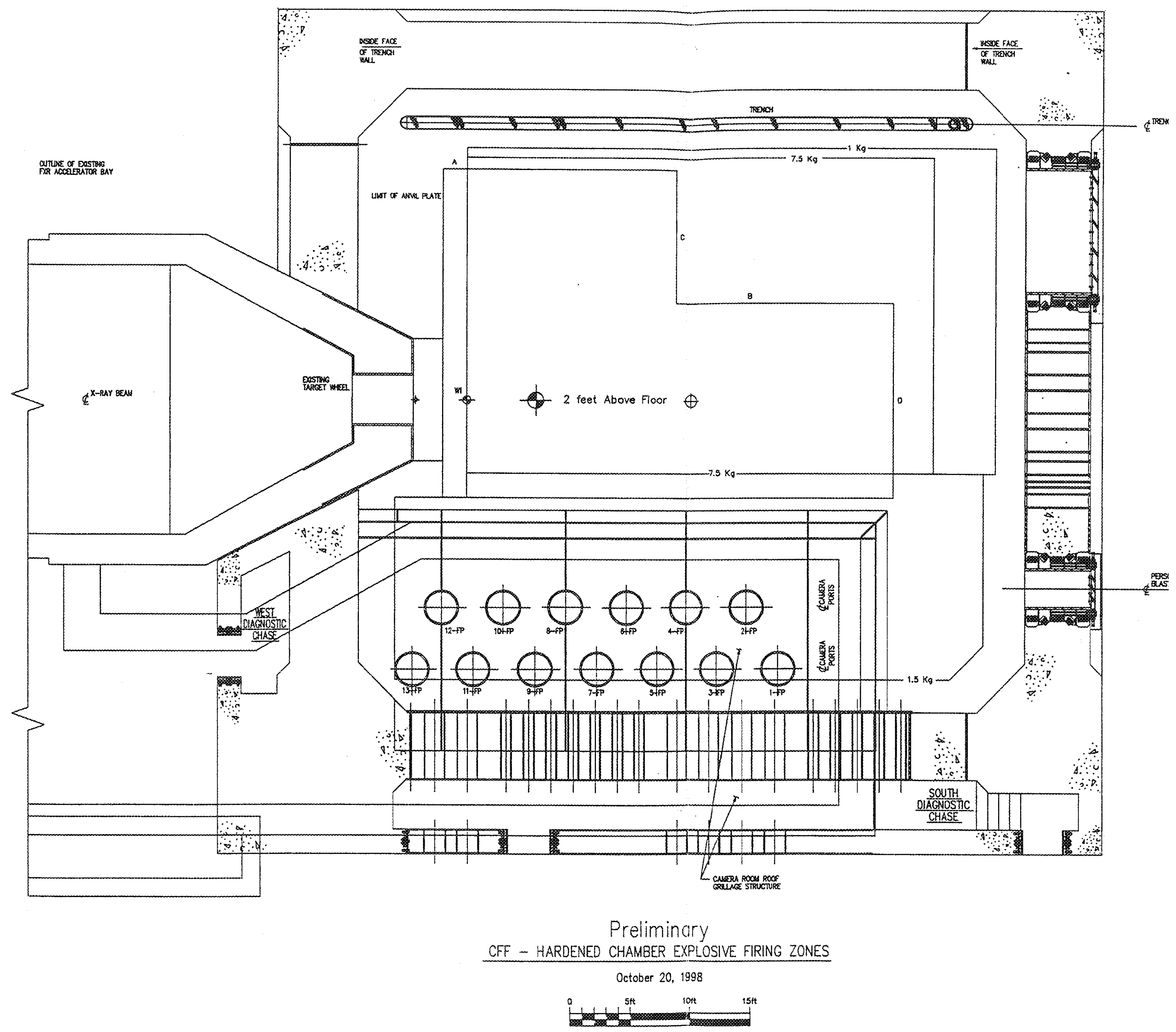




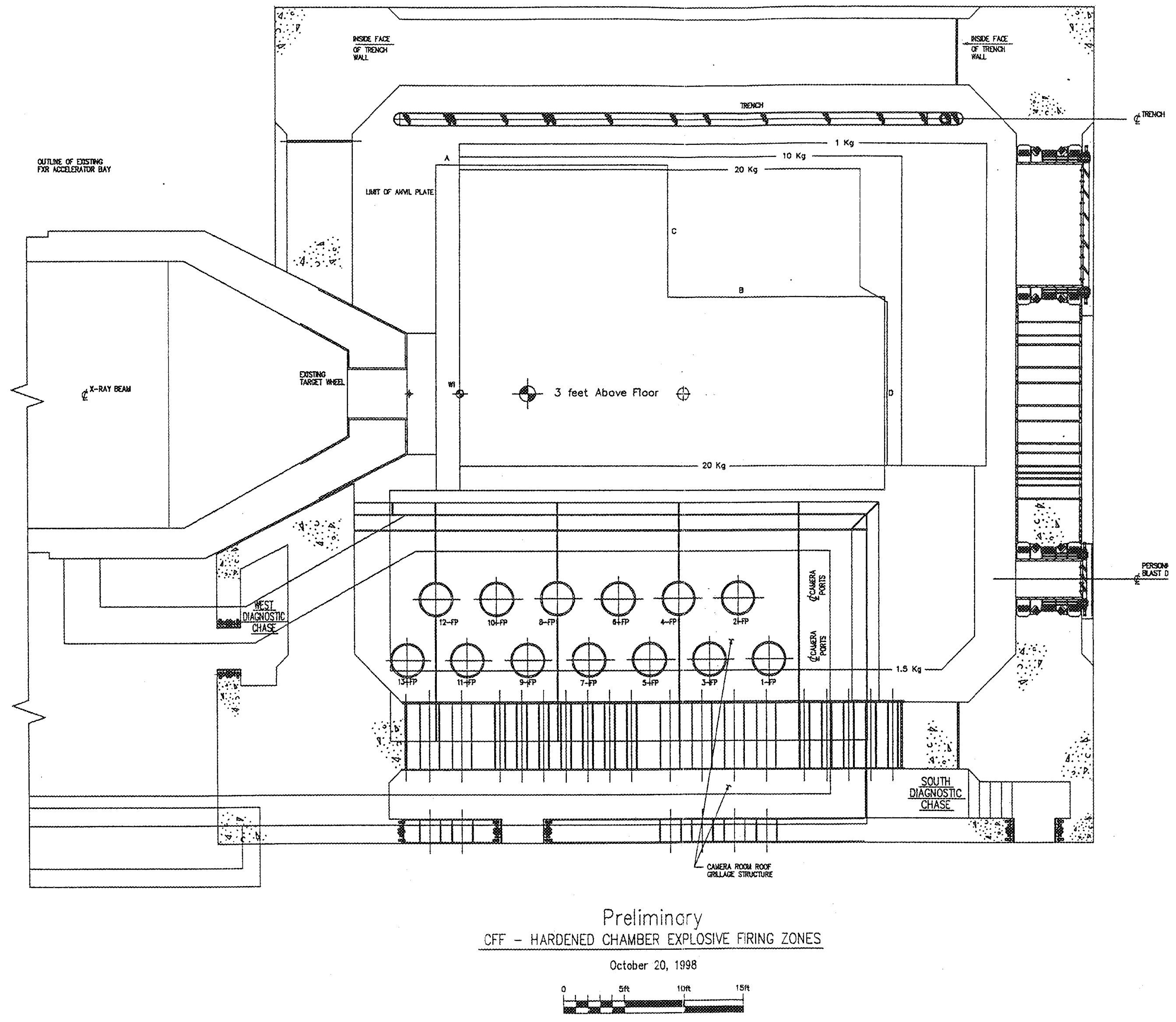




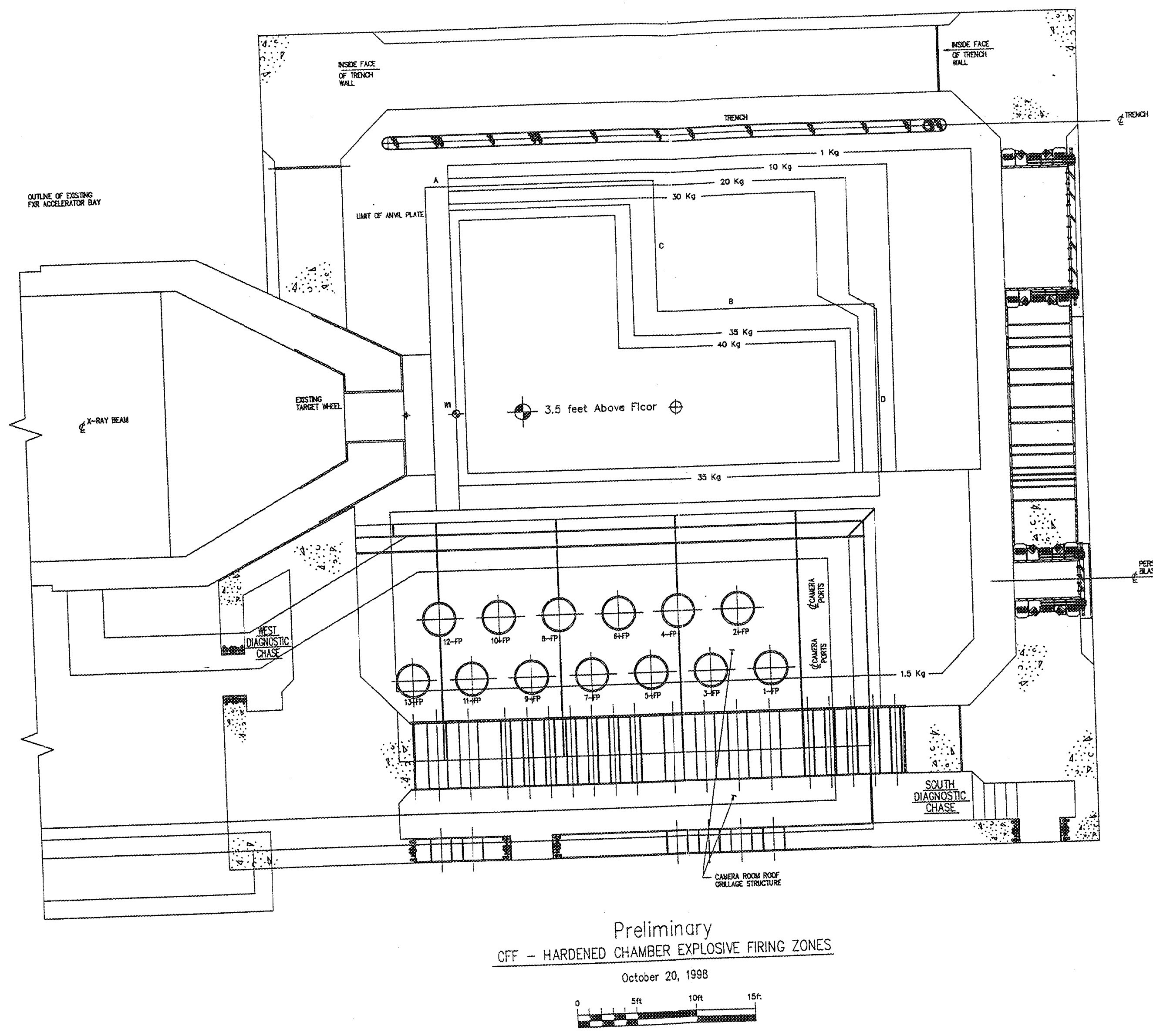




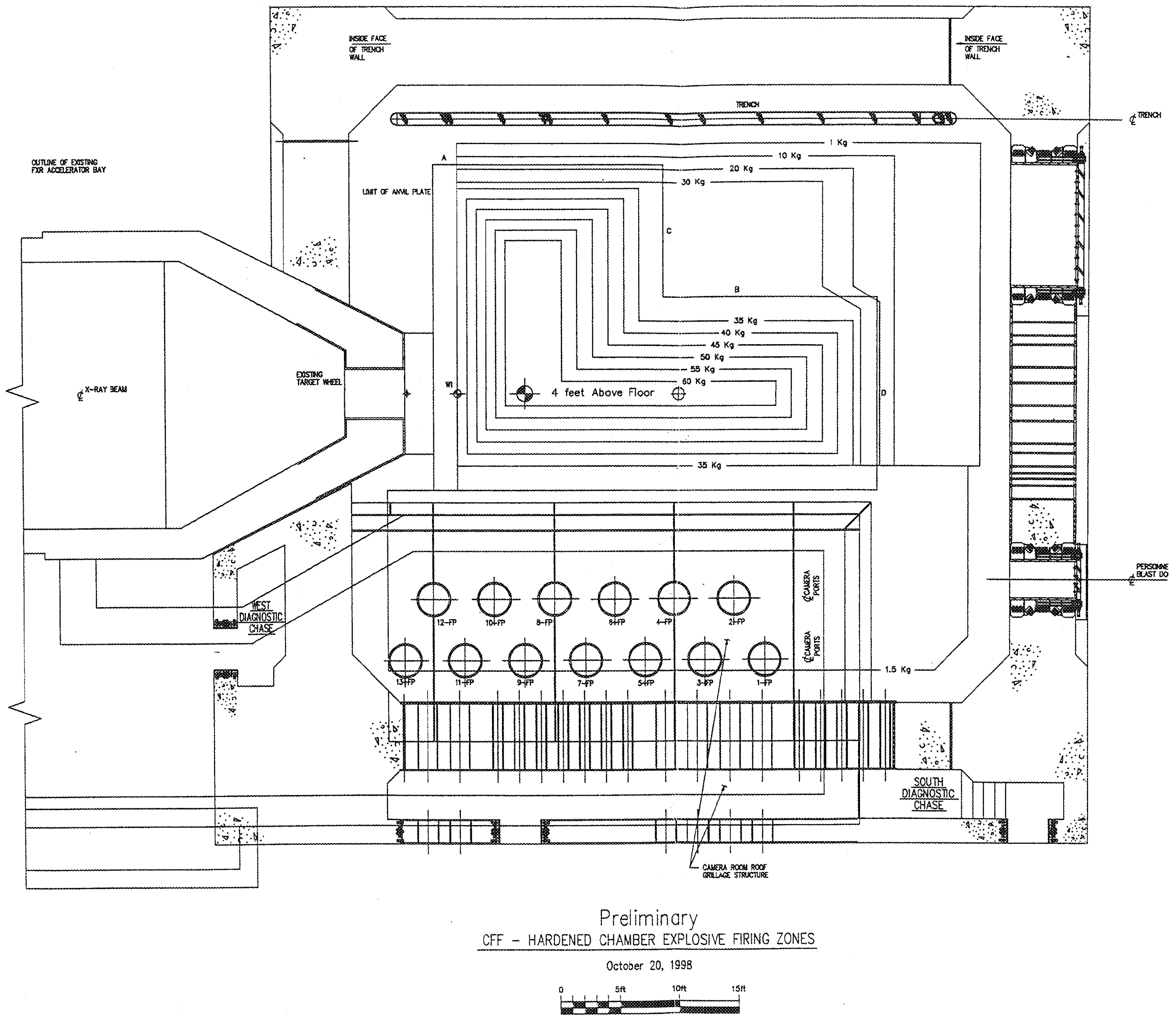




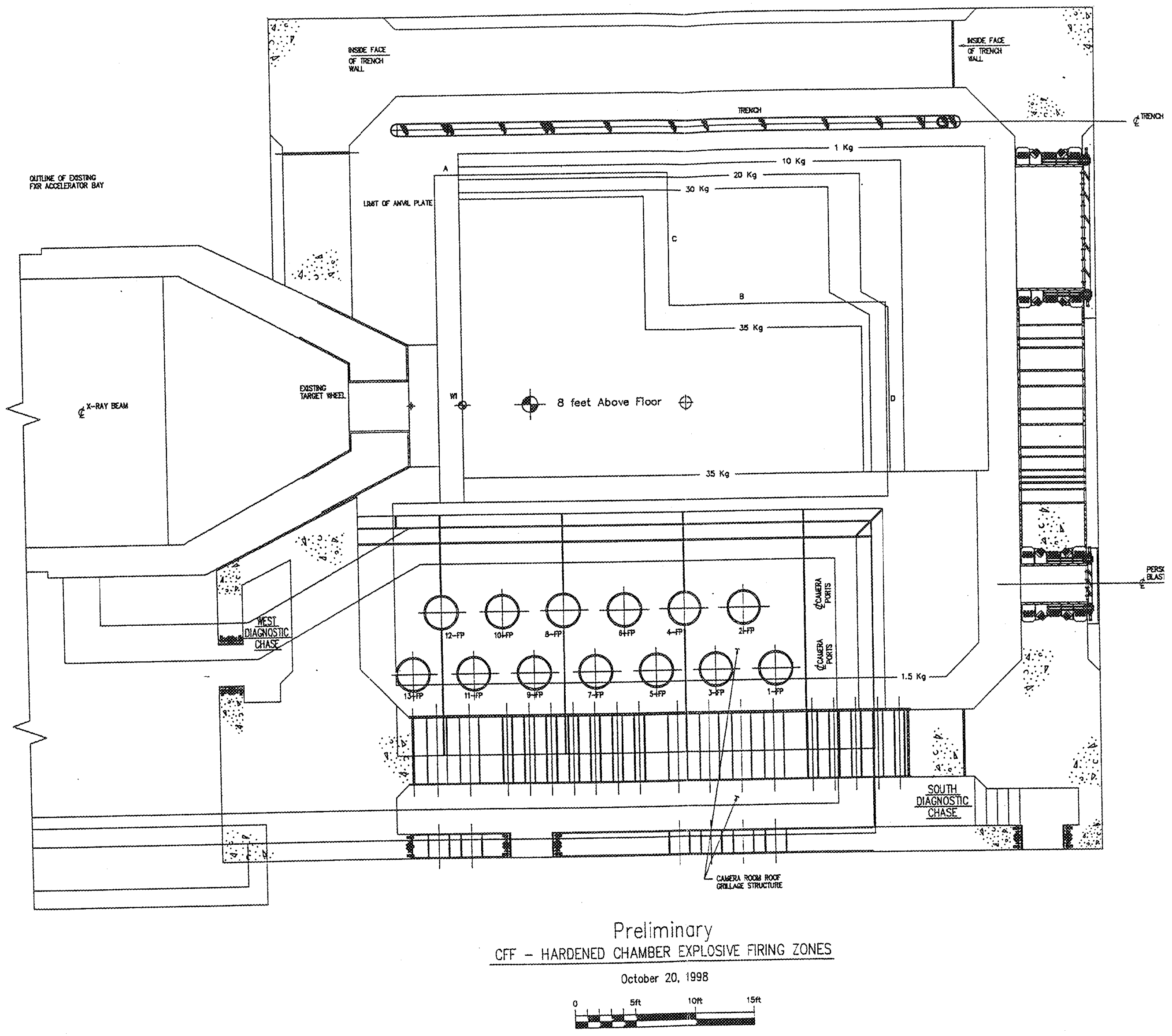




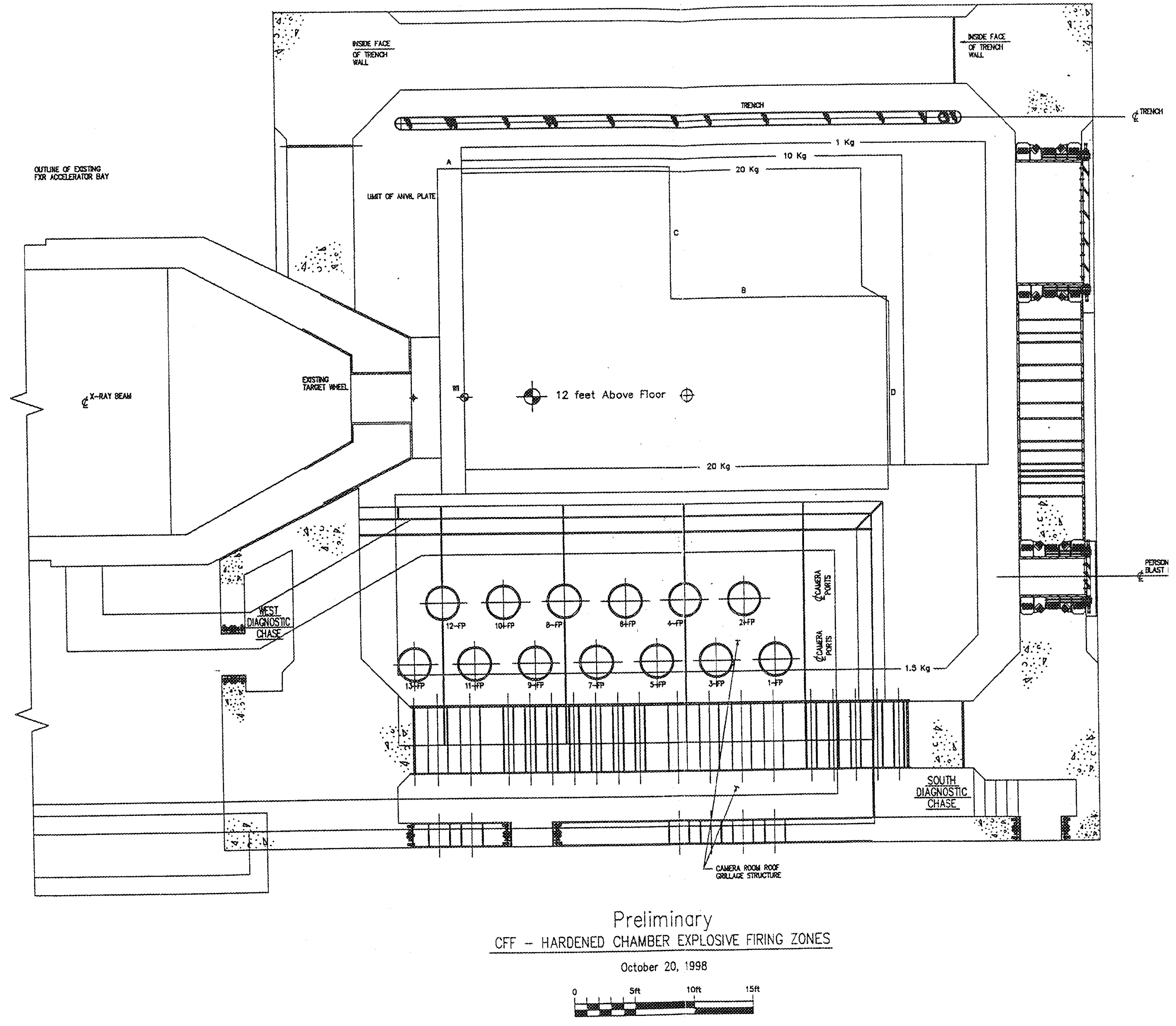




\section{APPENDIX B}

The SHOCK code calculations for the 206.3 $\mathrm{lb}$ charge of TNF are given for the floor and roof of the firing chamber to illustrate the technique and because this charge results in the highest loading on the respective surfaces. This is followed by calculations for the $120.3-\mathrm{lb}$ charge, giving the maximum pressures on the east and west walls (no bullnose accounted for). One of a series of code calculations is given to illustrate the reduced area feature of the code. In this case, a virtual blast door on the inside of the chamber wall is being considered. The two remaining plots are the calculated peak average pressures and impulses on the virtual door from charges of various weights as they are moved along a bisecting normal line to the door. 
$\cdots$
1
1<smiles></smiles>

A

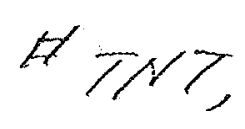

\author{
$C E R T E P E D$ \\ PROGRAM SHOCK \\ VERSION 1.0
}

\begin{abstract}
$* * * * * * * * * * * * * * * * * * * * * * * * * * * * * * * * * * * * * * * * * * * * * * * * * * * * * * * * *$ PROGRAM FOR CALCULATION OF AVERAGE BARRIER REFLECTED SHOCK PRESSURES AND IMPULSES DUE TO AN INCIDENT WAVE AND REFLECTED WAVES FRON ONE TO FOUR REFLECTION SURFACES. ORIGINAL PROGRAM "PAIMPRES" DEVELOPED BY AMMANN AND WHITNEY MODIFIED TO "SHOCK" BY NAVAL CIVIL ENGINEERING LAB
\end{abstract}

$+$

DATA SET TITLE:

A206FS FCOOR

A. CHARGE WEIGHT, LBS.............. 206.30

B. DISTANCE TO BLAST SURFACE, FT........ 4.00

C. WIDTH OF BLAST SURFACE, FT........... 55.00

D. HEIGHT OF BLAST SURFACE, FT......... 51.00

E. HORIZONTAL (X) DISTANCE TO CHARGE FROM REFLECTING SURFACE NO. 2, FT...... 27.50

F. VERTICAL ( $\Psi$ ) DISTANCE TO CHARGE FROM REFLECTING SURFACE NO. 1, FT...... 25.50

G. REFLECTING SURFACES "I" FOR FULL REFLECTION, "0" FOR NONE

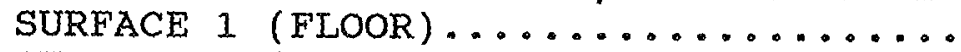
SURFACE 2 (LEFT SIDEWALL) .............

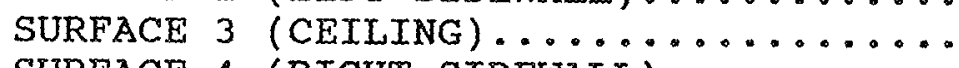
SURFACE 4 (RIGHT SIDEWALL)...........

H. REDUCED SURFACE CALCULATION............ No ${ }^{1}$

ANALYSTS RESULTS

AVERAGE SHOCK PRESSURE AND SCALED SHOCK IMPULSE ON BLAST SURFACE DUE TO WAVES OFF REFLECTING SURFACES DUE TO INCIDENT WAVE

SURFACE

IMPULSE

PRESSURE

$$
1
$$

8.6

16.9

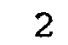

7.9

14.3
3

8.6

16.9
4

7.9

14.3
24.3

400.9

MAXIMUM AVERAGE SHOCK PRESSURE AND TOTAL AVERAGE SHOCK IMPULSE ON BLAST SURFA SCALED IMPULSE 57.2

IMPULSE $\quad 338.2$

PRESSURE $\quad 400.9$

IMPULSE DURATION ON BLAST SURFACE $=1.69 \mathrm{MS}$

SCALED IMPULSES HAVE BEEN DIVIDED BY $W * *(1 / 3)=5.91$

SCALED IMPULSES ARE PSI-MS/LBS**1/3, IMPULSES ARE PSI,-MS, PRESSURES ARE PSI 


\section{PHRSONS H LOCATIOX}

1

PROGRAM SHOCK

VERSTON 1.0

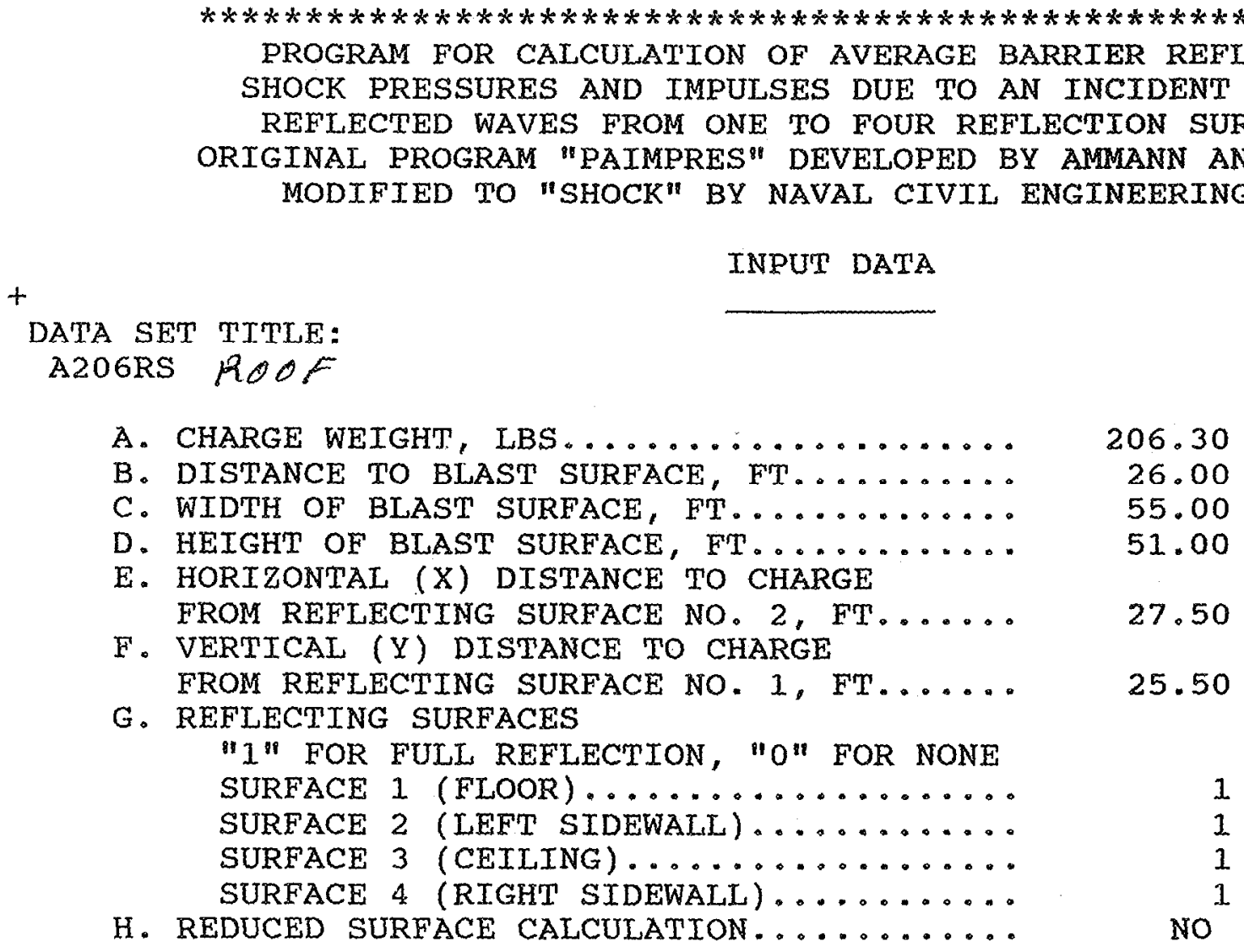

ANALYSIS RESULTS

AVERAGE SHOCK PRESSURE AND SCALED SHOCK IMPULSE ON BLAST SURFACE

SURFACE

IMPULSE

PRESSURE DUE TO WAVES OFF REFLECTING SURFACES

$\begin{array}{cccc}1 & 2 & 3 & 4 \\ 12.7 & 10.8 & 12.7 & 10.8 \\ 33.6 & 25.3 & 33.6 & 25.3\end{array}$

DUE TO INCIDENT WAVE

$$
\begin{aligned}
& 20.0 \\
& 78.0
\end{aligned}
$$

MAXIMUM AVERAGE SHOCK PRESSURE AND TOTAL AVERAGE SHOCK IMPULSE ON BLAST SURFA

$$
\begin{array}{rr}
\text { SCALED IMPULSE } & 67.0 \\
\text { IMPULSE } & 395.6 \\
\text { PRESSURE } & 78.0
\end{array}
$$

IMPULSE DURATION ON BLAST SURFACE $=10.14 \mathrm{MS}$

SCALED IMPULSES HAVE BEEN DIVIDED BY $W *(1 / 3)=5.91$

SCALED IMPULSES ARE PSI MS/LBS**1/3, IMPULSES ARE PSI-MS, PRESSURES ARE PSI 


\title{
35 KG WEAREST EAST WALL ON ANVIL
}

PROGRARY SHOCK

VERSION 1.0

\begin{abstract}
$* * * * * * * * * * * * * * * * * * * * * * * * * * * * * * * * * * * * * * * * * * * * * * * * * * * * * * * * *$
PROGRAM FOR CALCULATTON OF AVERAGE BARRIER REFLECTED SHOCK PRESSURES AND IMPULSES DUE TO AN INCIDENT WAVE AND REFLECTED WAVES FROM ONE TO FOUR REFLECTION SURFACES. ORIGINAL PROGRAM "PAIMPRES" DEVELOPED BY AMMANN AND WHITNEY MODIFIED TO "SHOCK" BY NAVAL CIVIL ENGINEERING LAB
\end{abstract}

$+$

DATA SET TITLE:

EW35KG

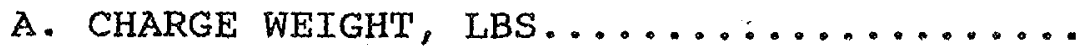

B. DISTANCE TO BLAST SURFACE, FT.........

C. WIDTH OF BLAST SURFACE, FT...........

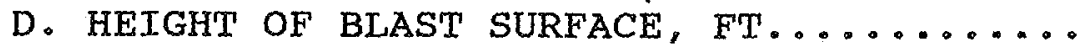

E. HORIZONTAL (X) DISTANCE TO CHARGE FROM REFLECTING SURFACE NO. 2, FT......

F. VERTICAL (Y) DISTANCE TO CHARGE FROM REFLECTING SURFACE NO. 1, FT......

G. REFLECTING SURFACES

"1" FOR FULL REFLECTION, "O" FOR NONE

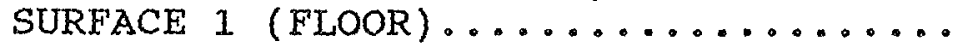

SURFACE 2 (LEFT STDEWALL)..........

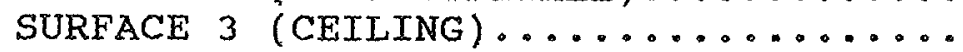

SURFACE 4 (RIGHT STDEWALL) ..........

H. REDUCED SURFACE CALCULATION.
120.12

13.00

51.00

30.00

19.50

4.00

ANALYSIS RESULTS

AVERAGE SHOCK PRESSURE AND SCALED SHOCK IMPULSE ON BLAST SURFACE DUE TO WAVES OFF REFLECTING SURFACES

$\begin{array}{rrrrrr}\text { SURFACE } & 1 & 2 & 3 & 4 & \\ \text { IMPULSE } & 19.5 & 9.3 & 9.3 & 6.6 & 21.8 \\ \text { PRESSURE } & 105.7 & 19.4 & 18.1 & 10.3 & 126.9\end{array}$

MAXIMUM AVERAGE SHOCK PRESSURE AND TOTAL AVERAGE SHOCK IMPULSE ON BLAST SURFA SCALED IMPULSE 66.5

IMPULSE $\quad 328.2$

PRESSURE $\quad 126.9$

IMPULSE DURATION ON BLAST SURFACE $=5.18 \mathrm{MS}$

SCALED IMPULSES HAVE BEEN DIVIDED BY $W * *(1 / 3)=4.93$

SCALED IMPULSES ARE PSI-MS/LBS**1/3, IMPULSES ARE PSI-MS, PRESSURES ARE PSI 


\title{
PARSONS B LOCATIOX
}

$120.312 T N T$

PROGRAM SHOCK

VERSION 1.0

\begin{abstract}
$* * * * * * * * * * * * * * * * * * * * * * * * * * * * * * * * * * * * * * * * * * * * * * * * * * * * * * * * *$
PROGRAM FOR CALCULATION OF AVERAGE BARRIER REFLECTED

SHOCK PRESSURES AND IMPULSES DUE TO AN INCTDENT WAVE AND REFLECTED WAVES FROM ONE TO FOUR REFLECTION SURFACES. ORIGINAL PROGRAM "PAIMPRES" DEVELOPED BY AMMANN AND WHITNEY MODIFIED TO "SHOCK" BY NAVAL CIVIL ENGINEERING LAB
\end{abstract}

DATA SET TITLE:

INPUT DATA

B120WW

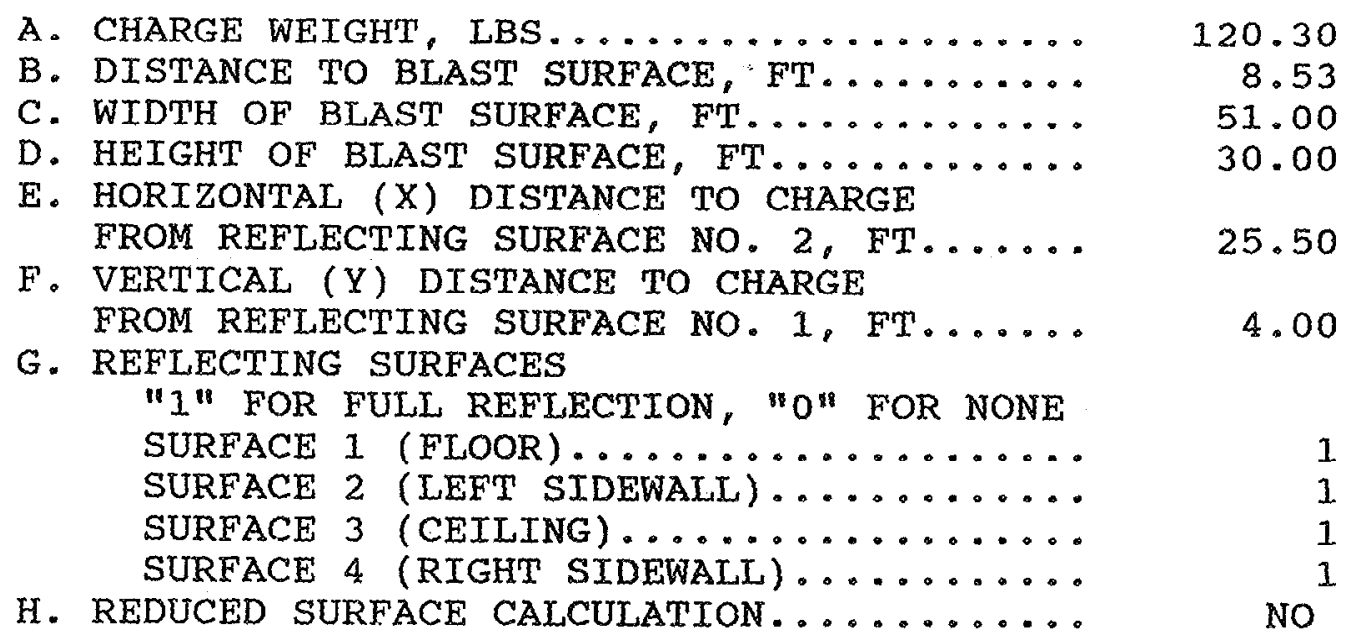

ANALYSIS RESULTS

AVERAGE SHOCK PRESSURE AND SCALED SHOCK IMPULSE ON BLAST SURFACE DUE TO WAVES OFF REFLECTING SURFACES DUE TO INCIDENT WAVE

SURFACE

TMPULSE

PRESSURE 1 20.1 180.3 2 7.4 12.8 3

8.9

16.8 4

7.4

12.8
24.3

234.7

MAXIMUM AVERAGE SHOCK PRESSURE AND TOTAL AVERAGE SHOCK IMPULSE ON BLAST SURFA SCALED IMPULSE IMPULSE

PRESSURE 68.2 336.4 234.7

IMPULSE DURATION ON BLAST SURFACE $=2.87$ MS

SCALED IMPULSES HAVE BEEN DIVIDED BY $W * *(1 / 3)=4.94$

SCALED IMPULSES ARE PSI-MS/LBS**1/3, IMPULSES ARE PSI-MS, PRESSURES ARE PSI 
$35 \mathrm{KG}$ NEAREST EMST WAL ON AXVLL 1 REDUCEO AREA - DOOR FAASE

\author{
PROGRAM SHOCK \\ VERSION 1.0
}

\begin{abstract}
$* * * * * * * * * * * * * * * * * * * * * * * * * * * * * * * * * * * * * * * * * * * * * * * * * * * * * * * * *$ PROGRAM FOR CALCULATION OF AVERAGE BARRIER REFLECTED SHOCK PRESSURES AND IMPULSES DUE TO AN INCIDENT WAVE AND REFLECTED WAVES FROM ONE TO FOUR REFLECTION SURFACES. ORIGINAL PROGRAM "PAIMPRES" DEVELOPED BY AMMANN AND WHITNEY MODIFIED TO "SHOCK" BY NAVAL CIVIL ENGINEERING LAB
\end{abstract}

$+$

DATA SET TITLE:

EW35DR

A. CHARGE WEIGHT, LBS................

B. DISTANCE TO BLAST SURFACE, FT.........

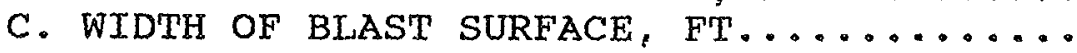

D. HEIGHT OF BLAST SURFACE, FT...........

E. HORIZONTAL (X) DISTANCE TO CHARGE

FROM REFLECTING SURFACE NO. 2 , FT......

F. VERTICAL (Y) DISTANCE TO CHARGE

FROM REFLECTING SURFACE NO. 1, FT......

G. REFLECTING SURFACES

" 1 " FOR FULL REFLECTION, "O" FOR NONE

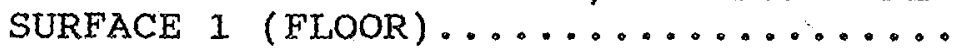

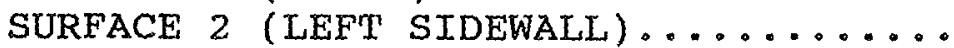

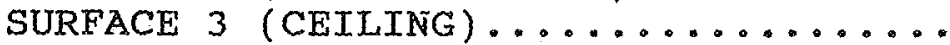

SURFACE 4 (RIGHT SIDEWALL) ..........

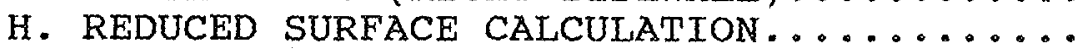

CORNERS OF REDUCED AREA; $X, Y$; FT

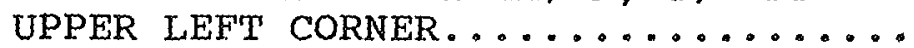

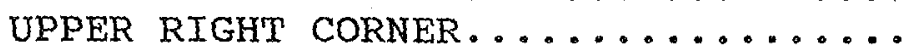

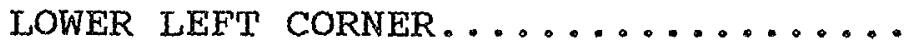

LOWER RIGHT CORNER.............
120.12

13.00

51.00

30.00

19.50

4.00

1
1
1
1
YES

$\begin{array}{rr}6.52 & 13.00 \\ 16.52 & 13.00 \\ 6.52 & 0.00 \\ 16.52 & 0.00\end{array}$

ANALYSIS RESULTS

AVERAGE SHOCK PRESSURE AND SCALED SHOCK IMPULSE ON REDUCED SURFACE

SURFACE

IMPULSE

PRESSURE DUE TO WAVES OFF REFLECTING SURFACES

$\begin{array}{cr}1 & \\ 32.0 & 1 \\ 266.3 & 2 \\ & \\ \text { SHOCK } & \text { PRES. } \\ \text { SE } & 91.7 \\ \text { LSE } & 452.5 \\ \text { URE } & 303.4\end{array}$

DUE TO INCIDENT WAVE

$\begin{array}{rrr}2 & 3 & 4 \\ 11.9 & 7.3 & 4.8 \\ 25.7 & 11.2 & 5.4\end{array}$

35.8

303.4

MAXIMUM AVERAGE SHOCK PRES. AND TOTAL AVERAGE SHOCK IMPULSE ON REDUCED SURFAC

$\begin{array}{rr}\text { SCALED TMPULSE } & 91.7 \\ \text { IMPULSE } & 452.5 \\ \text { PRESSURE } & 303.4\end{array}$

IMPULSE DURATION ON BLAST SURFACE $=2.98 \mathrm{MS}$

SCALED IMPULSES HAVE BEEN DIVIDED BY $W * *(1 / 3)=4.93$

SCALED IMPULSES ARE PSI-MS/LBS**1/3, IMPULSES ARE PSI-MS, PRESSURES ARE PSI 


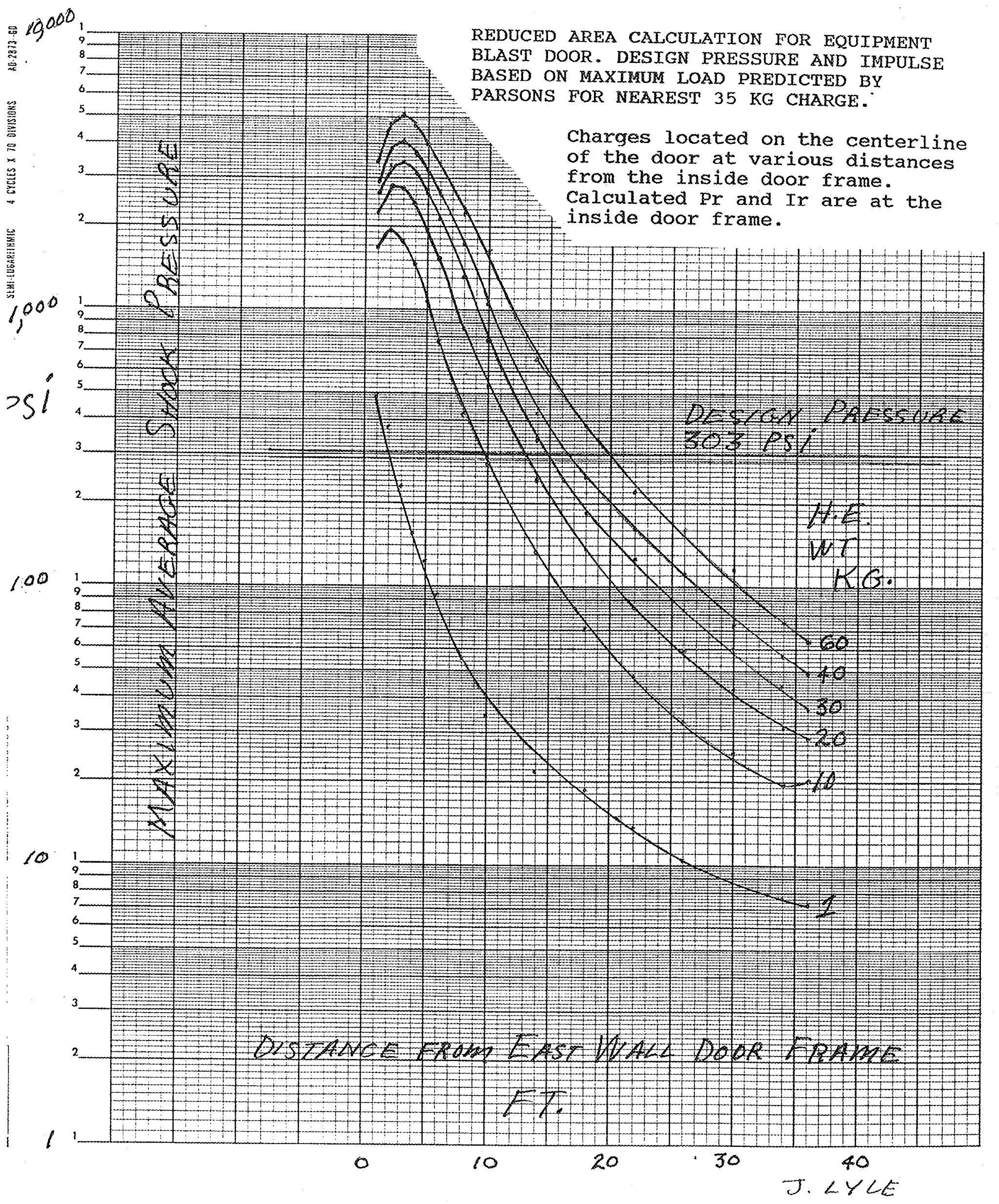




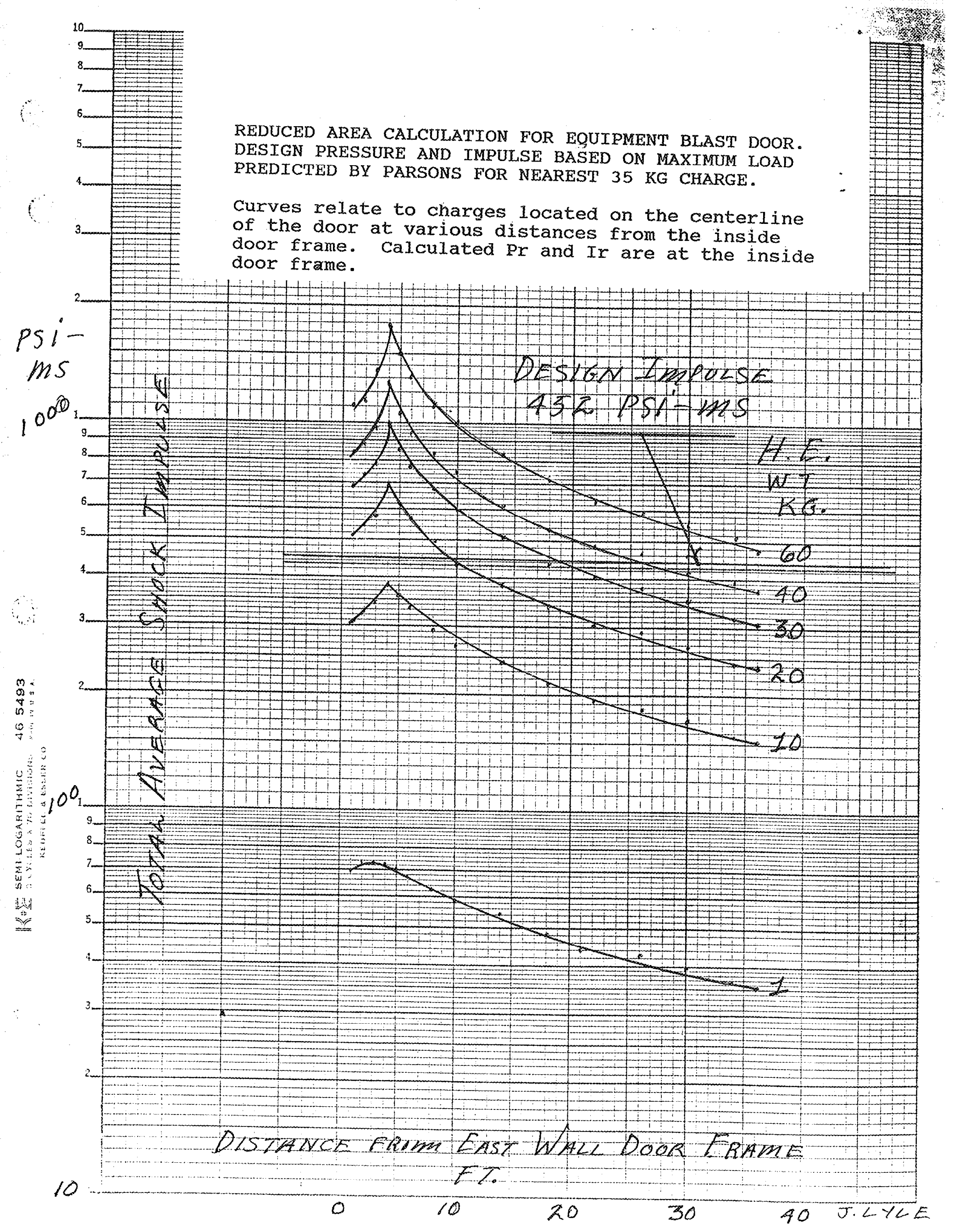




\section{APPENDIX C}

These hand calculations illustrate the methods of Reference 2 that can be used to calculate explosive firing zones. The use of the SHOCK code has replaced these methods principally because of its speed and its , reduced area feature which allows a determination of average shock and impulse on specified areas and points. 
file 24,3 of

The kef Loading Curves for the Firing Chamber of the Contained Firing Faun CCFF. 300 .

C.Y. KING

April 1998 


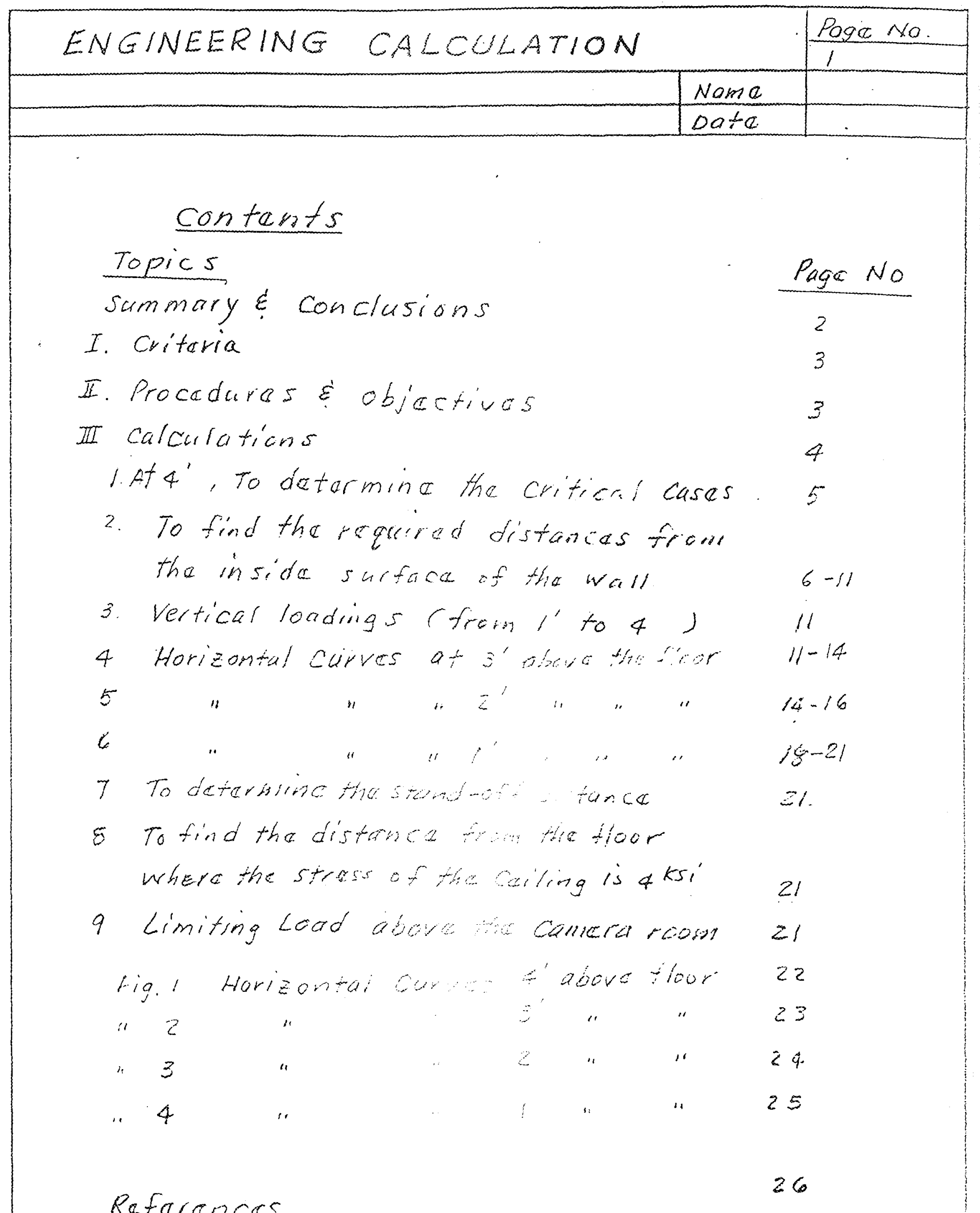




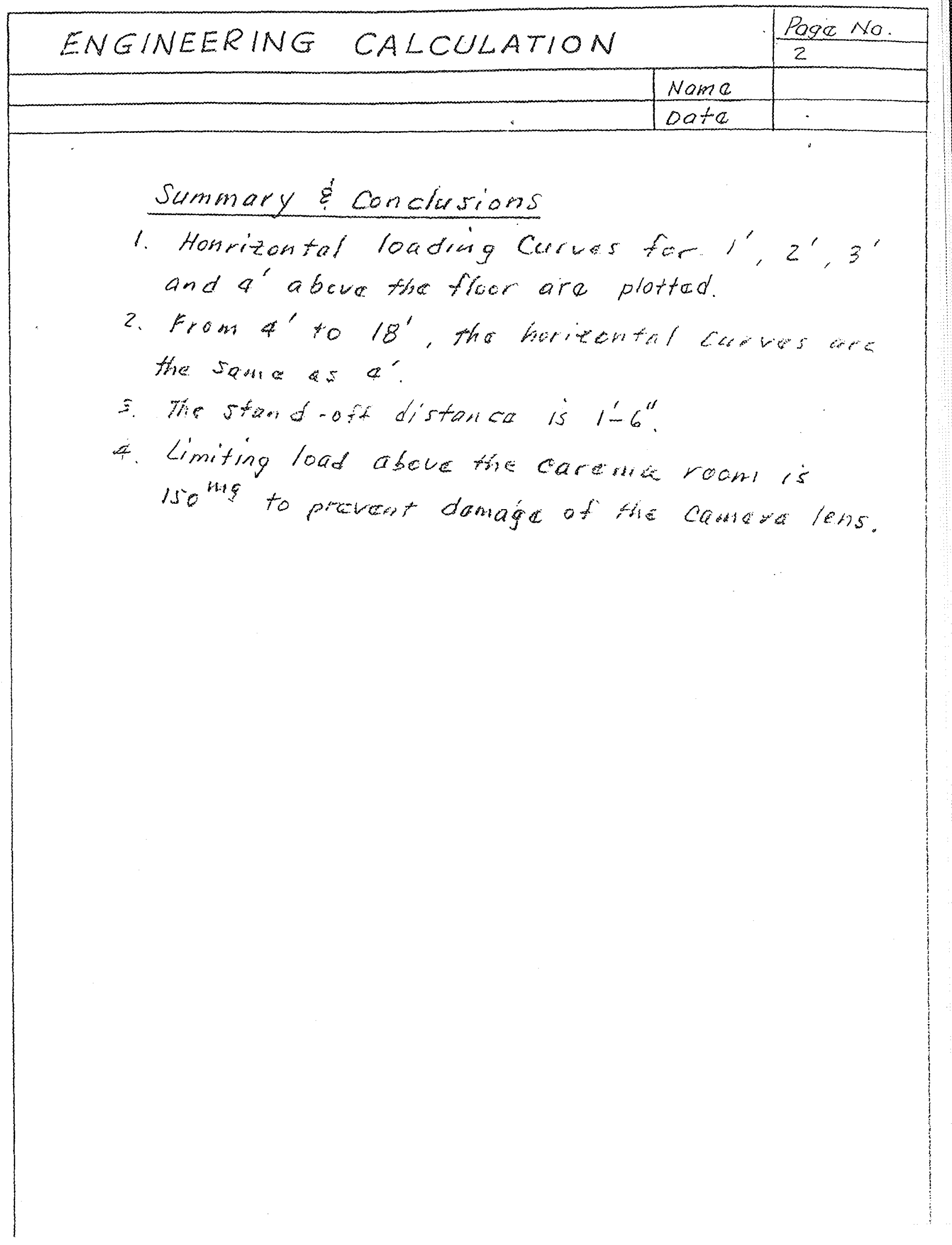




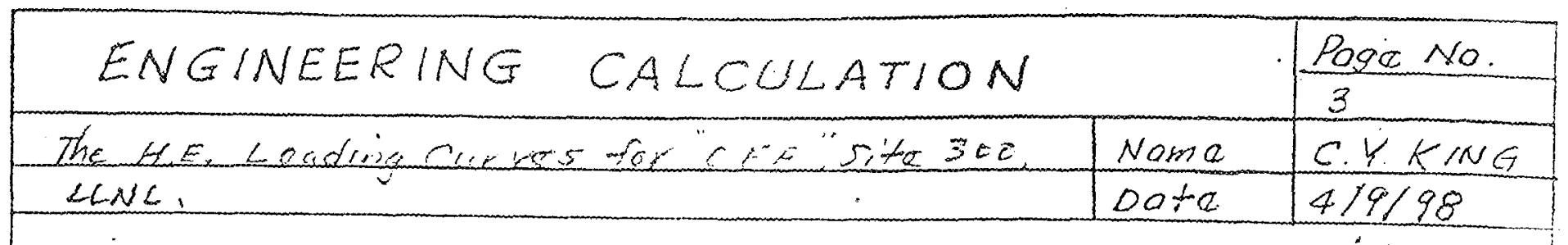

I. Criteria:

1. At 4' above the floor:

a. $35^{\text {KG HIE }}$ at the edges where is $z^{\prime}$ inside of the bounties of the anvil plates.

b. $60^{\text {KG HIE }}$ at the canter of the chamber.

2. The Maximum contrite compressive stress of the floor is $12^{\mathrm{ksi}}$. ansi concrete is at elsa-wherc. Ret: Parsons Infrastructure \& Technology Group. "CEF" Title I, $100 \%$ Design Review, "Cha anvil and floor Blast Analysis For "CFF", CLNC, dated 3 se lar Appendix 7 , Summery of Maximum compressive stress along trio Flour Dapta." )

II. Procedures \& client

1. To calculate the required horton wal distances flew the inside service of the wall, for 3,599 to wo

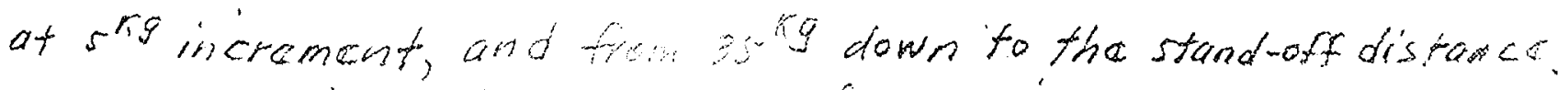
2. To determine the ashen: of HaE. in $\mathrm{kg}$ at the different elevations Wire loading Curves.

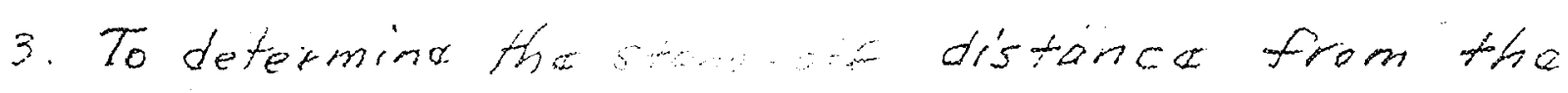
velds.

4 The end product is of the His loading curves for the Find chamber of the contain d firing facility $C a \cdot$ different elevations. 


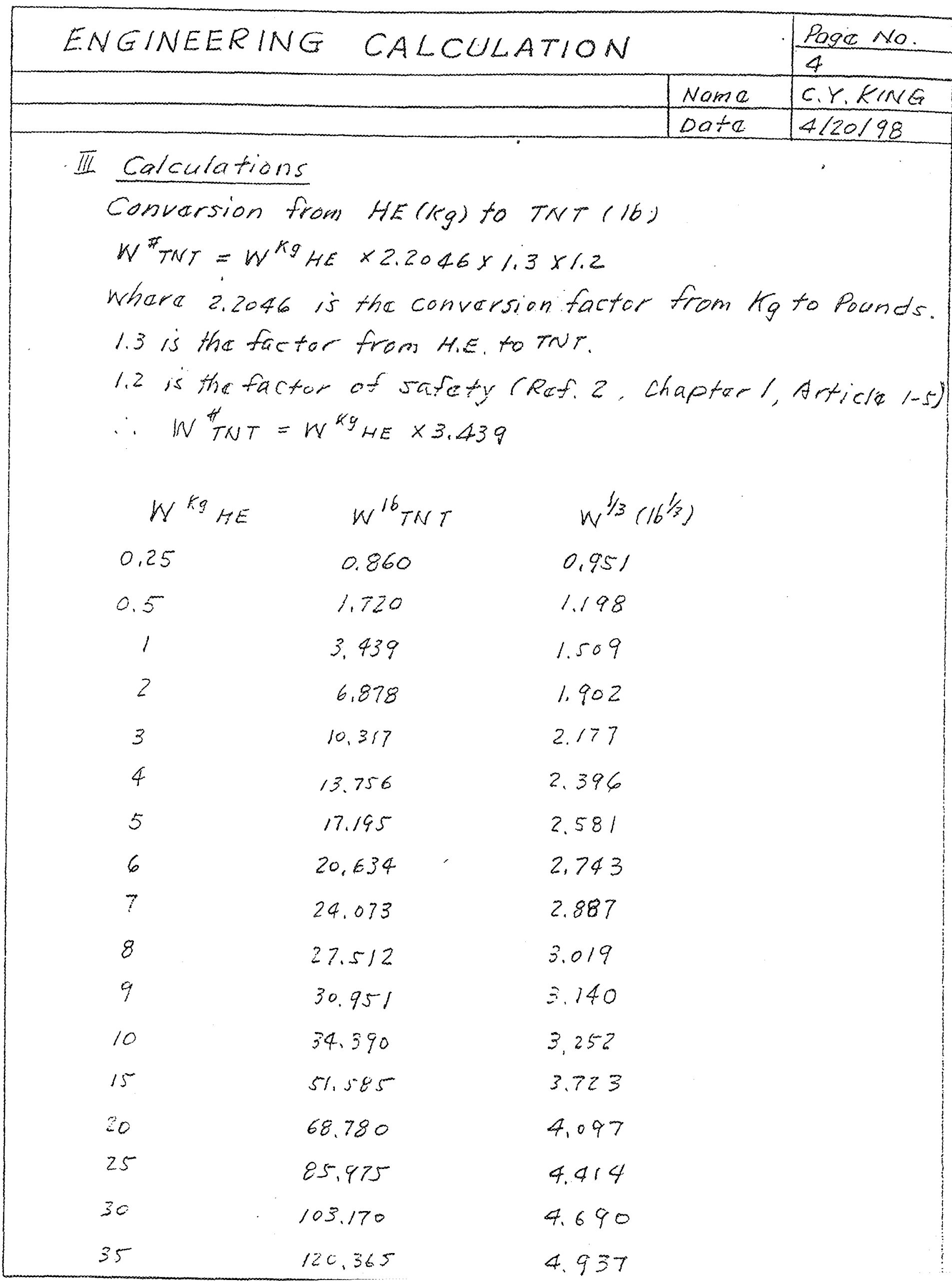




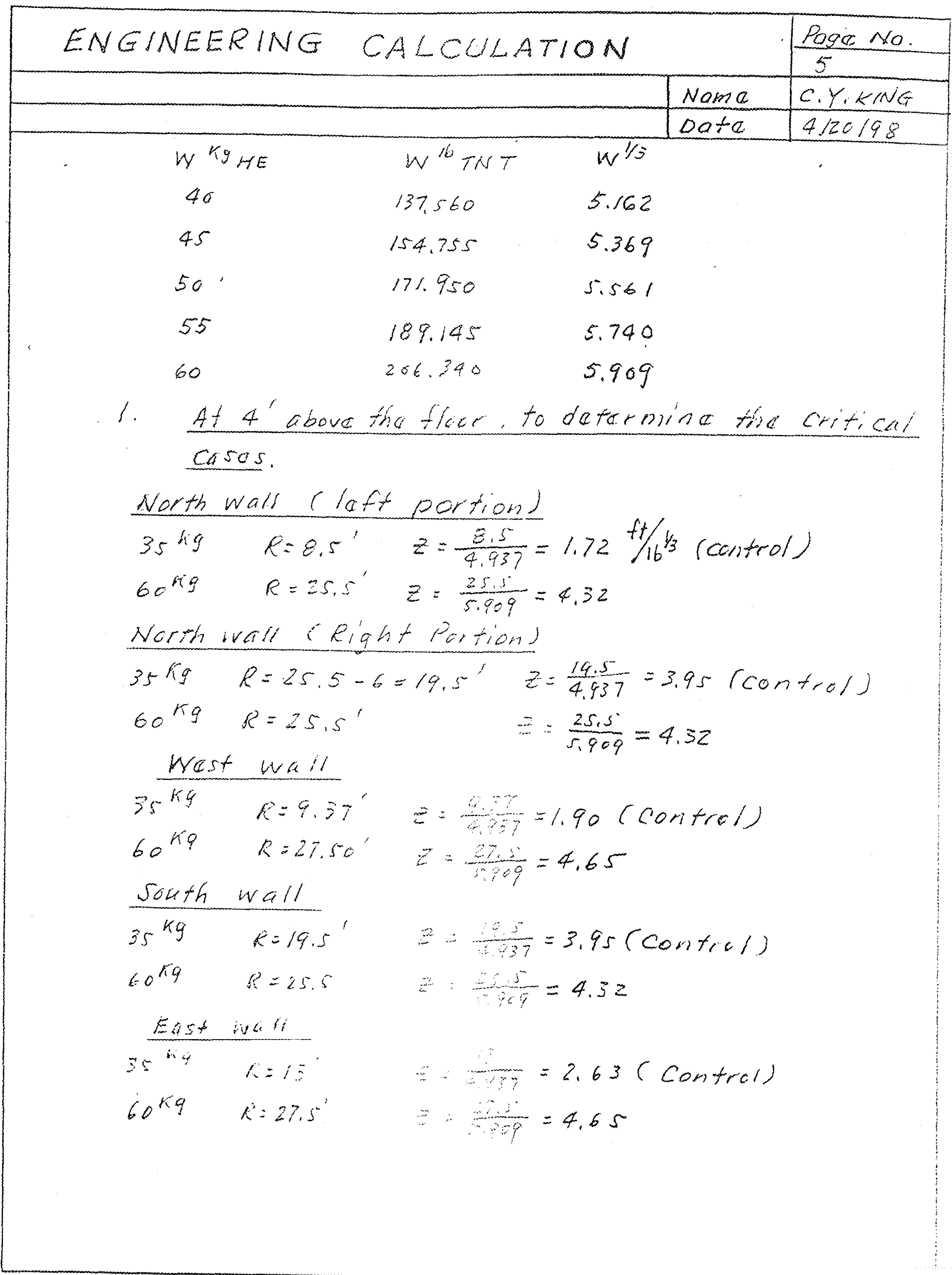




\begin{tabular}{|l|l|l|}
\hline ENGINEERING CALCULATION & $\frac{\text { Pogo No. }}{6}$ \\
\hline & Nama & C.Y 1 HING \\
\hline & Data & 4120198 \\
\hline
\end{tabular}

2. To fine the required distances form the inst er Surface of the wall.

North wall (left portion)

From $35^{\circ}$ hg up

$$
\begin{aligned}
& 35^{\mathrm{kg}} R=8.5\left(8^{\prime}-6^{\prime \prime}\right) \quad Z=\frac{8.5}{4.939}=1.72 \\
& R_{40}=1.72 \times 5.162=8.879^{\prime}\left(8^{\prime}-10^{\prime 5} 8^{\prime \prime}\right) \\
& R_{45}=1.72 \times 5.369=9.235^{\prime} \quad\left(9^{\prime}-278^{\prime \prime}\right) \\
& R_{50}=1.72 \times 5.561=9.565^{\prime} \quad\left(9^{\prime}-68^{\prime \prime}\right) \\
& R_{55}=1.72 \times 5.740=9.873^{\prime} \quad\left(9^{\prime}-10 \%\right) \\
& R_{60}=1.72 \times 5.909=10.183^{\prime \prime} \quad\left(10^{\prime}-2^{\prime \prime}\right)
\end{aligned}
$$

Fran $35^{\mathrm{kg} g}$ down

$$
\begin{aligned}
& R_{30}=1.72 \times 4.690=8.067(8-0 \% ") \\
& R_{25}=1.72 \times 4.414=7.592\left(7-7 \%{ }^{\prime \prime}\right) \\
& R_{2 Q}=1.72 \times 4.697=7.211\left(7^{\prime}-25 / 5\right) \\
& R_{15}=1.72 \times 3.723=6.404(6-47 / 8) \\
& R_{10}=1.72 \times 3.252=5.593\left(5^{\prime}-7 \%\right) \\
& R_{i}=1.72 \times 3.140=5.401 \quad\left(5^{\prime}-4 \frac{78}{8}\right) \\
& R_{q}=1.72 \times 3.019=5.193 \quad(5-23 / 8) \\
& R_{7}=1.72 \times 7.88 \%=9.966 \quad\left(9^{\prime}-115 \%\right. \text { ') } \\
& R_{6}=1.72 \times 2.743=4.718\left(4^{\prime}-85 \%\right) \\
& R_{5}=1.72 \times 2.581=4.439\left(4^{\prime} \cdot 5 \%\right) \\
& R_{4}=1.72 \times 2.396=4.121\left(4^{\prime}-11^{\prime \prime}\right) \\
& R_{3}=1.72 \times 2.177=3.744\left(3^{\prime}-9^{\prime \prime}\right) \\
& R_{2}=1.72 \times 1.902=3.271\left(3^{\prime}-3 / 4\right) \\
& \hat{R}_{1}=1.72 \times 1.509=2.596\left(2^{\prime}-7 / 4\right)
\end{aligned}
$$

Note: All dimensions inaction eq won are in nearest eighth. 


\section{ENGINEERING CALCULATION}

$\left.R_{0.5}=1.72 \times 1.198=2.06\right)^{\prime}\left(2-00^{\prime \prime \prime}\right)$

$R 0.25=1.72 \times 0.951=1.636^{\prime}\left(1-.7 \overline{4}^{\prime \prime}\right)$

$$
\begin{aligned}
& \text { North wall (Right Portion) } \\
& \text { Frem } 35^{\mathrm{kg}} \text { up } \\
& k=19.5^{\prime} \quad z=\frac{19.5}{4.937}=3.95 \\
& R_{35}=9.95 \times 4.937=19.5^{\prime}\left(19^{\prime}-6^{\prime \prime}\right) \\
& R C O=\$ .95 \times 5.162=20.390^{\prime}\left(20^{\prime}-4^{3} / 4^{\prime \prime}\right) \\
& R_{45}=3.95 \times 5.369=21.208^{\prime}\left(20^{\prime}-212^{\prime \prime}\right) \\
& R_{50}=3.95 \times 5.561=21.966^{\prime}\left(21^{\prime}-115^{\prime \prime}\right) \\
& R_{5 S}=3.95 \times 5.740=22.673^{\circ}\left(22^{\prime}-81 / 88^{\prime \prime}\right) \\
& R E_{c}=3.95 \times 5.909=23.341^{\prime}\left(23{ }^{\prime}-4 y_{\varepsilon}^{\prime \prime}\right) \\
& \text { From } 35^{\mathrm{kg}} \text { down } \\
& R_{30}=3.95 \times 9.690=18.5266^{\prime}(16- \\
& R_{25}=3.95 \times 4.414=17.455^{\prime}(17 \cdot 5) \\
& R_{20}=3.95 \times 4.047=16.188^{\prime}\left(16^{\prime}-2 /{ }^{\prime \prime}\right) \\
& R_{15}=3.95 \times 3.72 .3=14.706^{\prime}\left(16^{\prime}(2 / 2 ")\right. \\
& R_{10}=3.95 \times 3.252=12.845(100) \\
& R=3.95 \times 3.140=12.403 \\
& R_{\varepsilon}=3.95 \times 3.019=11.925 \\
& R_{7}=3.95 \times 2.887=11.404 \\
& R_{6}=3.95 \times 2.743=10.835(0) \\
& R_{5}=3.95 \times 2.581=10.195^{\prime}(1.38) \\
& R_{4}=3.95 \times 2.396=9.464 \\
& R_{3}=3.95 \times 2.177=8.599(8)
\end{aligned}
$$




\section{ENGINEERING CALCULATION}

\begin{tabular}{|l|l|} 
& Page No \\
\hline Name & C.Y.KNG \\
\hline Date & $4 / 20 / 98$ \\
\hline
\end{tabular}

$$
\begin{aligned}
& R_{2}=3.95 \times 1.902=7.513^{\prime}\left(7-6 \frac{t^{\prime \prime}}{4}\right) \\
& R_{1}=3.95 \times 1.509=5.961^{\prime}\left(5^{\prime}-11_{8}^{\prime \prime}\right) \\
& R_{0.5}=3.95 \times 1.198=4.732\left(7^{\prime}-88_{8}^{\prime}\right) \\
& \left.R_{0.25}=3.95 \times 0.951=3.757^{\prime}(3-9)^{\prime}\right)
\end{aligned}
$$

\section{West Wall}

\section{Frow $35^{\text {ky }}$ up}

$$
R_{35}=1.9 \times 4.937=9.37^{\prime}\left(9-4 \frac{1}{2}\right)
$$

$R_{40}=1.9 \times 5.162=9.808^{\prime}\left(9^{\prime}-9.3 \%\right)$

$$
R_{45}=1.9 \times 5.369=10.201^{\prime}\left(10^{\prime}-2 / 2\right)
$$$$
\left.R_{50}=1.9 \times 5.561=10.566^{\prime}\left(10^{\prime}-6\right)_{2}\right)
$$

$$
\begin{aligned}
& R_{55}=1.9 \times 5.740=10.906^{\prime}\left(10^{\prime}-10^{7} \%^{\prime \prime}\right) \\
& R_{40}=1.9 \times 5.909=11.227^{\prime}\left(11^{\prime}-23^{\prime \prime}\right)
\end{aligned}
$$

From 35 kg dows

$$
\begin{aligned}
& R_{30}=1.9 \times 4.690=8.911^{\prime}\left(8^{\prime}-11^{\prime \prime}\right) \\
& \left.R_{25}=1.9 \times 4.914=8.387^{\prime}\left(8^{\prime}-4^{3}\right)^{\prime \prime}\right) \\
& R_{z c}=1.9 \times 4.097=7.789^{\prime}(7-9 / 2) \\
& R_{15}=1.9 \times 3.723=7.079^{\prime}\left(7^{\prime}-1^{\prime \prime}\right) \\
& R_{10}=1.9 \times 3.252=6.179^{\circ}\left(6^{\prime}-2 / 4\right) \\
& R_{q}=1.945 .190=5.966^{\prime}\left(5^{\prime}-118_{8}^{\prime}\right) \\
& R_{\varepsilon}=1.9 \times 3.019=5.736^{\prime}\left(5^{\prime}-\varepsilon \bar{\nu}_{\bar{c}}^{\prime \prime}\right) \\
& R_{7}=1.9 \times 2.887=5.485^{\prime}\left(5^{\prime}-57_{8}^{\prime \prime}\right) \\
& R_{6}=1.9 \times 2.743=5.212^{\prime}\left(5^{\prime}-25 / 8^{\prime \prime}\right) \\
& R_{5}=1.9 \times 2.581=4.904^{\prime}\left(4^{\prime}-107 / 8^{\prime \prime}\right) \\
& k_{4}=1.9 \times 2.396=4.552^{\prime}\left(4^{\prime}-65 \varepsilon^{\prime \prime}\right)
\end{aligned}
$$




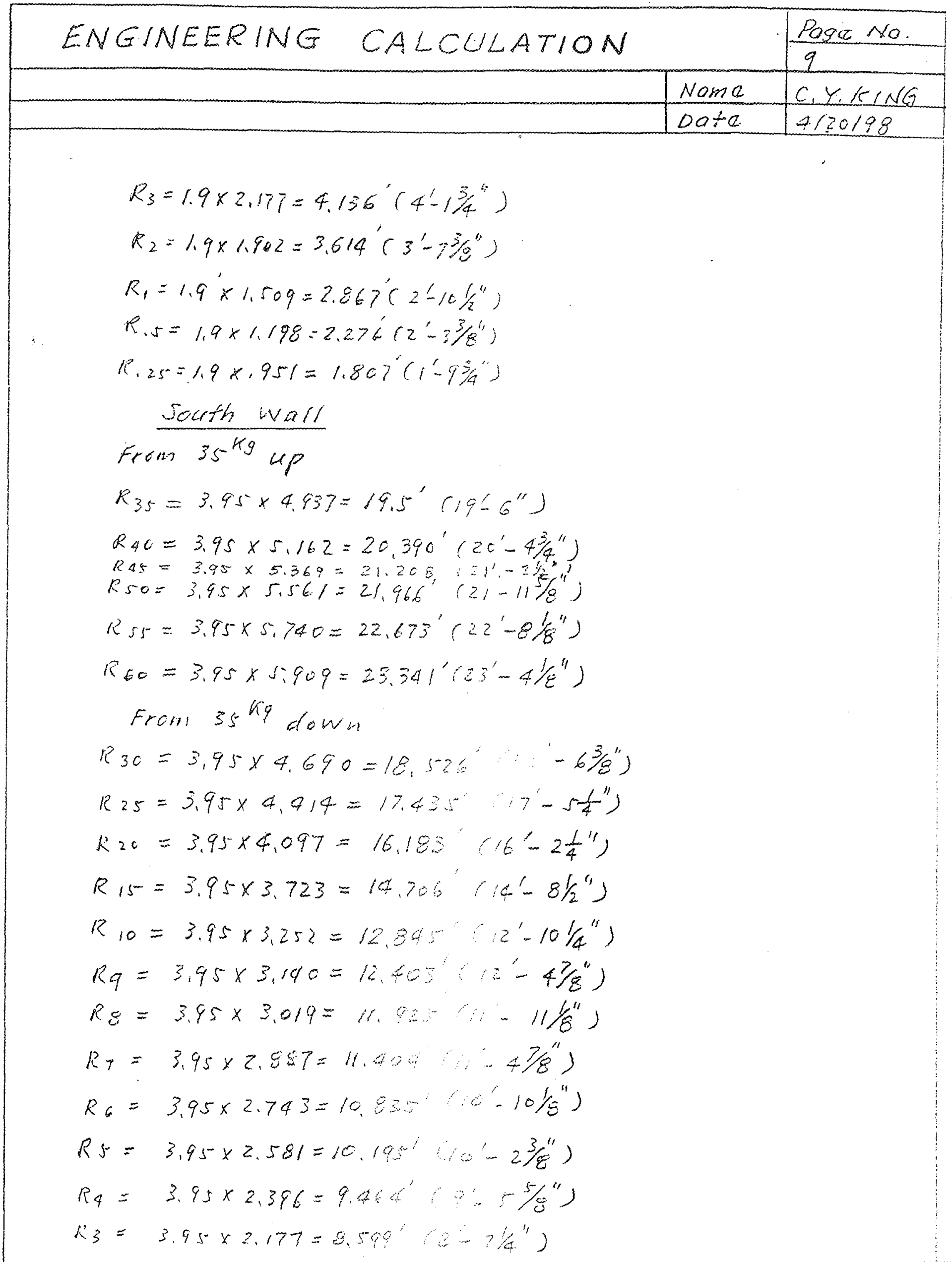




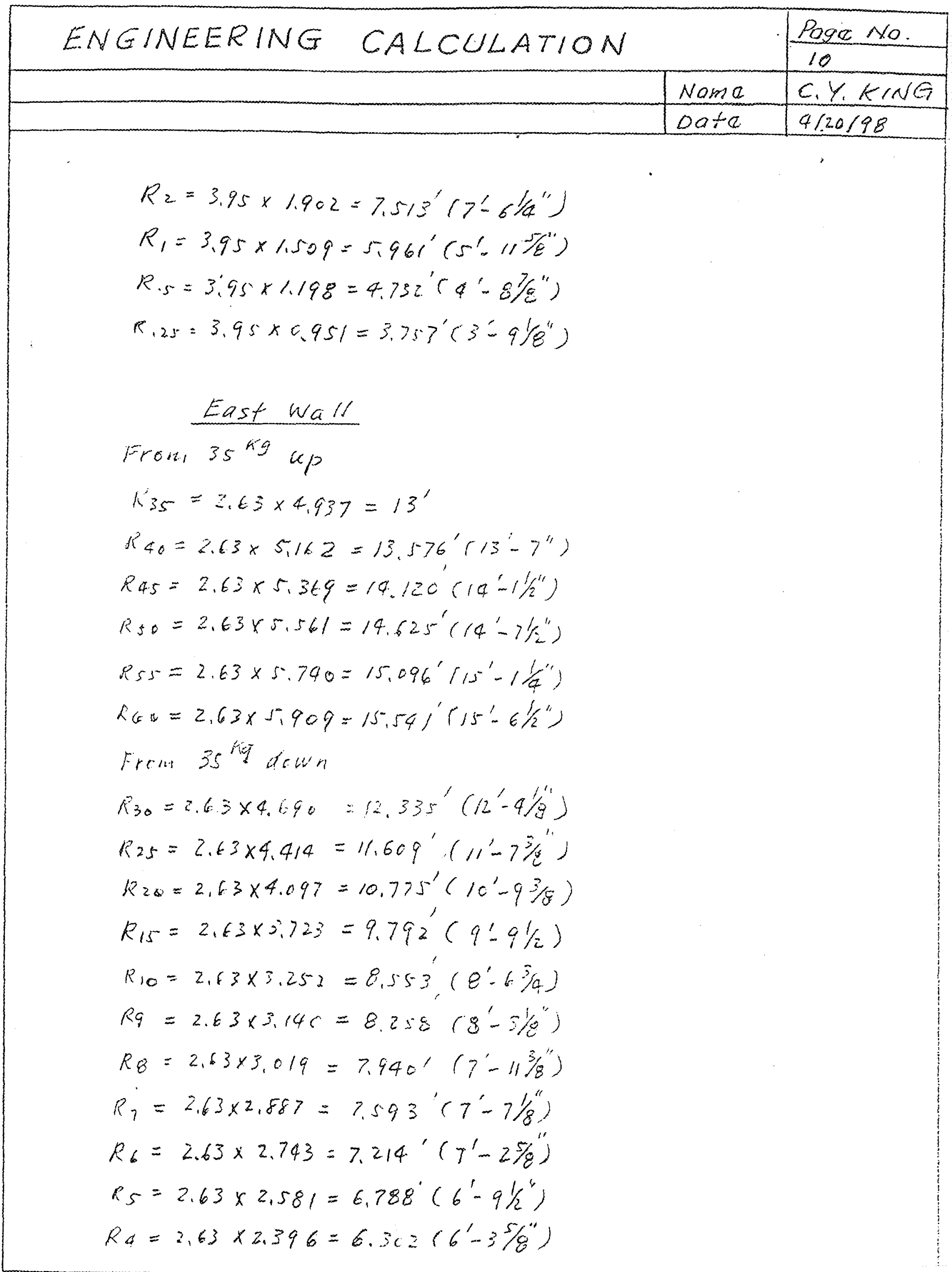




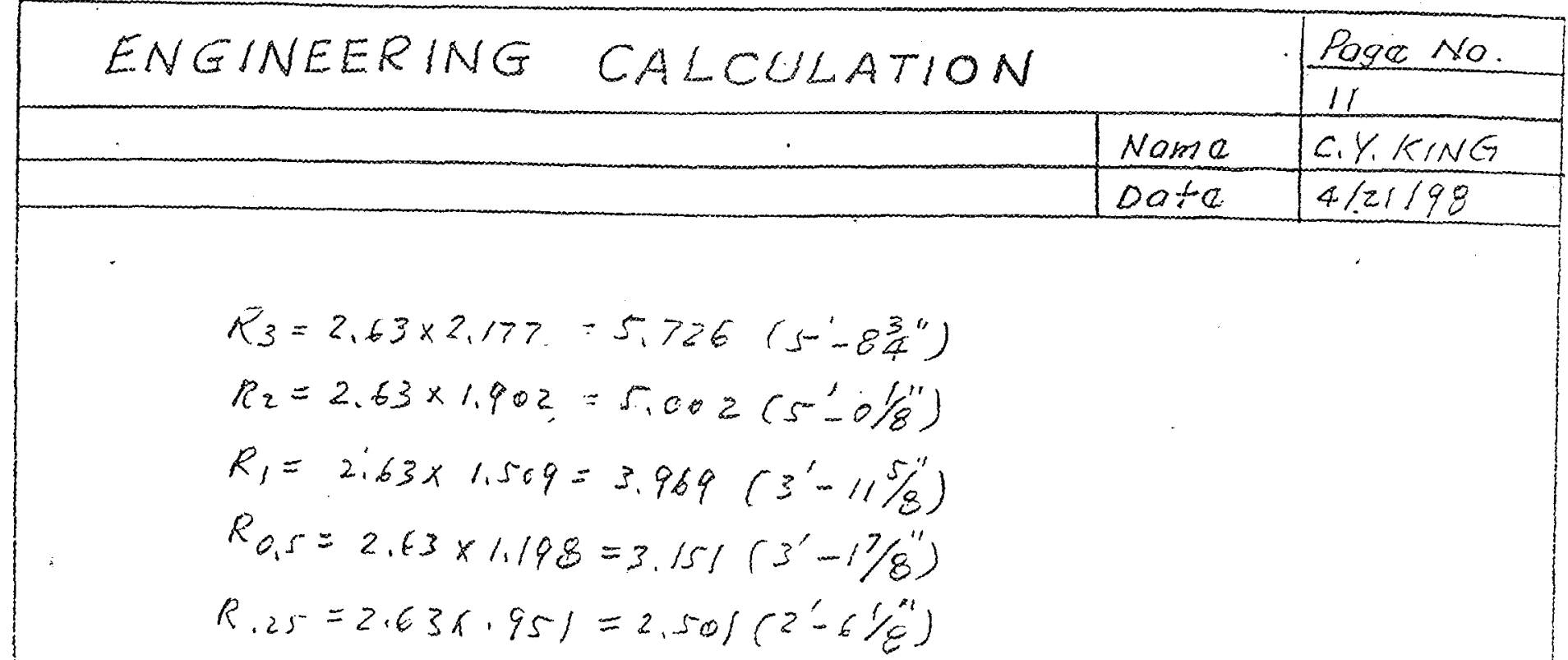

3. To determine the maximum loading at $y^{\prime} z^{\prime}$ and I' from the floor

$$
\begin{aligned}
& \text { at } 4^{\prime} \quad 35^{\mathrm{kg}} \quad z=\frac{4}{4.937}=.8102 \\
& 60^{49} \quad z=\frac{a}{1.909}=0.6769 \text { (control) } \\
& z=\frac{3}{N^{16}}=0.6769 \quad W^{1 / 3}=\frac{3}{16769}=4.4320 \\
& W=8 \pi .056 i^{H N T}=25.3144 \mathrm{~kg} \\
& a+z^{\prime} \\
& z=\frac{2}{m^{1 / 3}}=.6769 \quad W^{1 / 3}=\frac{2}{.6759}=2.9546
\end{aligned}
$$

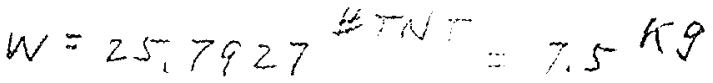

$$
\begin{aligned}
& a+1^{\prime} \\
& z=\frac{1}{w / 3}=.6769 \quad W^{1 / 3}=\frac{1}{.6769}=1.4773 \\
& W=3.2241^{H N T}=0.9375^{K g} \mathrm{HE}
\end{aligned}
$$

4. At 3' above the bor, to find the required distances from $\quad 2$ iss de of anvil plate +0 the insane surface of $\mathrm{log}$ wall.

$\frac{\text { North wall (Le te option) }}{1 / 3}$

$$
\begin{aligned}
& K=8.5^{\prime} \quad W^{1 / 3}=4.4320 \quad z=\frac{8.5}{4.4320}=1.9179 \mathrm{H} / \mathrm{w}^{1 / 3} \\
& 25^{\mathrm{kg}} \quad R_{25}=1.9179 \mathrm{R}=0.4=8.466^{\prime}\left(8^{\prime}-58^{\prime \prime}\right)
\end{aligned}
$$




\section{ENGINEERING CALCULATION}

$20 \mathrm{~kg} \quad R_{20}=1.9179 \times 4.097=7.0576^{\prime}(71-103 / 8)$

$15^{\mathrm{kg}} \quad R_{15}=1.9179 \times 3.723=7.1403^{\prime}\left(7-1 \frac{3}{4}{ }^{\prime \prime}\right)$

$10^{\mathrm{kg}} \cdot \quad R_{10}=1.4179 \times 3.252=6.2370^{\prime}\left(6^{\prime}-278^{\prime \prime}\right)$

$5^{\mathrm{kg}} \quad R_{5}=1.9179 \times 2.581=4.9500^{\prime}\left(4^{\prime}-111^{\prime \prime}\right)$

$4^{k 9} \quad R_{4}=1.9179 \times 2.396=4.5953^{\prime}\left(4^{\prime}-7 \frac{1}{4}\right)$

$3^{\mathrm{kg}} \quad R_{3}=1.9179 \times 2.177=4.1753^{\prime}\left(4^{\prime}-21 / 8^{\prime \prime}\right)$

$2 \mathrm{fig} \quad R_{2}=1.9179 \times 1.902=3.647 \varepsilon^{\prime}\left(3^{\prime}-77^{\prime \prime}\right)$

$1^{\mathrm{kq}} R_{1}=1.9179 \times 1.509=2.894^{\prime}\left(2^{\prime}-10{ }^{3} 4_{4}^{\prime \prime}\right)$

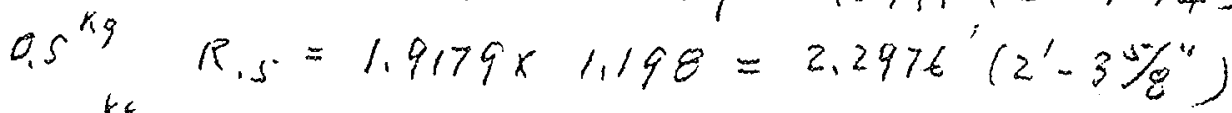

$0.25^{\mathrm{kg}}$ k.25 $=1.9179 \times .951=1.8239 /\left(1-10^{\prime \prime}\right)$

$$
\frac{\text { North wall(Right portion) }}{19.5^{\prime} \quad W^{1 / 3}=4.4320 \quad z=\frac{19.5}{4.4320}=4.3998}
$$

$25 \mathrm{~kg} \quad R_{25}=4.3948 \times 4.914=19.4207^{\prime}\left(19^{\prime}-51 / 8\right)$

$R_{i c}=4.3998 \times 4.097=18.0260^{\circ}\left(18^{\prime}-0,8^{\prime \prime}\right)$

$R_{15}=4.5998 \times 3.723=16.3825^{\prime}\left(16^{\prime}-45^{\prime \prime \prime}\right)$

$R_{10}=4.3998 \times 3.252=19.3083^{\prime}\left(14^{\prime}-33^{\prime \prime \prime}\right)$

$R_{5}=4.3998 \times 2.581=11.3559\left(11^{\prime}-4388^{\prime \prime}\right)$

$R_{A}=4.3995 \times 3.396=10.5419 \quad\left(10^{\prime}-6 \%\right)$

$R_{3}=4.3998 \times 2.177=9.5784\left(9^{\prime}-7^{\prime \prime}\right)$

$\left.A_{2}: 4.3998 \times 1.902=8.3684\left(8^{\prime}-4\right)^{\prime \prime}\right)$

$R_{1}=4.3998 \times 1.509=6.6393 \quad\left(6 \div .77^{\prime \prime \prime}\right)$

$k_{15}=4.3998 \times 1.198=2.2710\left(5-38^{\prime \prime}\right)$

$\left.R_{.25}=4.3998 \times .951=4.1842\left(4^{\prime}-2 / 4\right)^{\prime \prime}\right)$ 


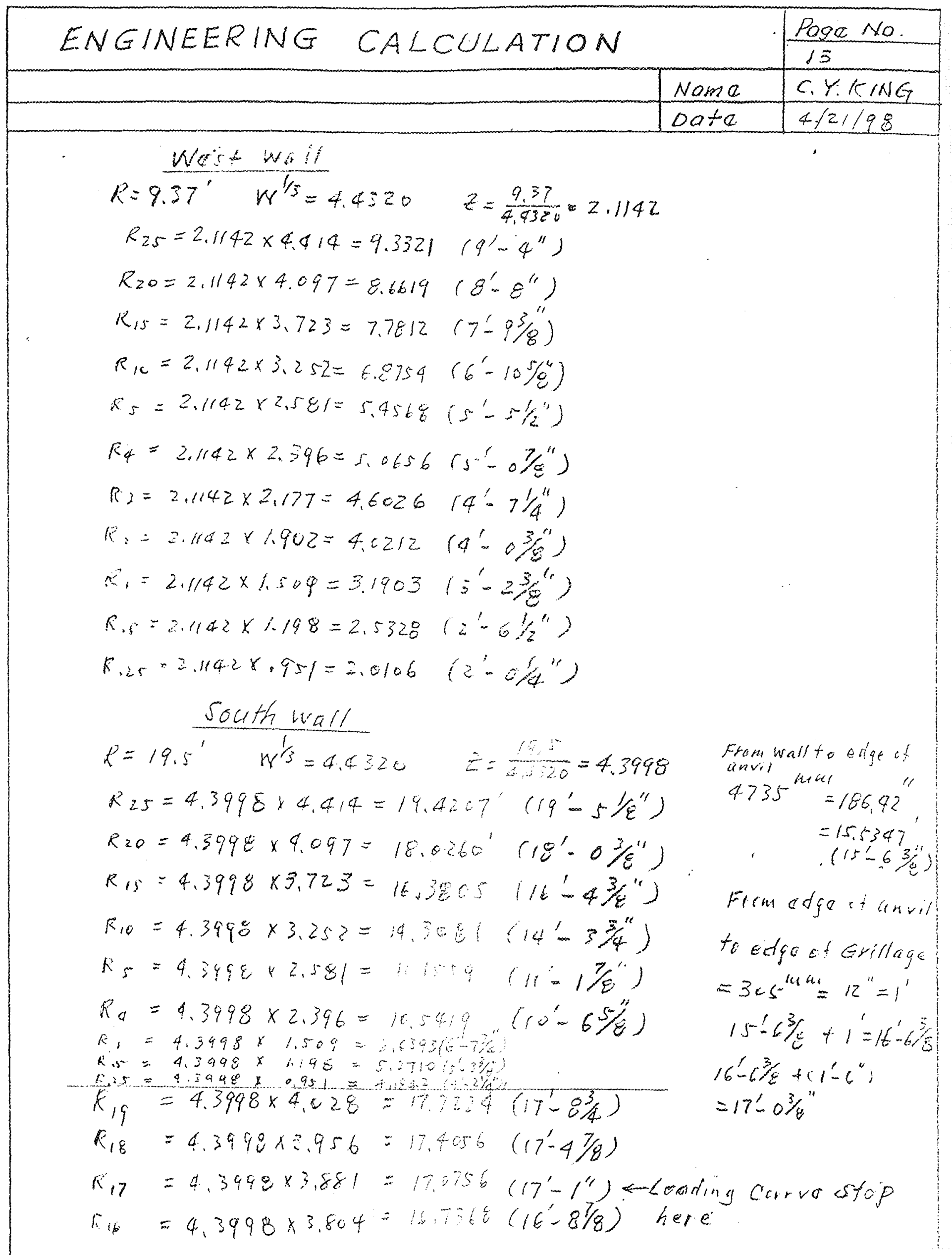




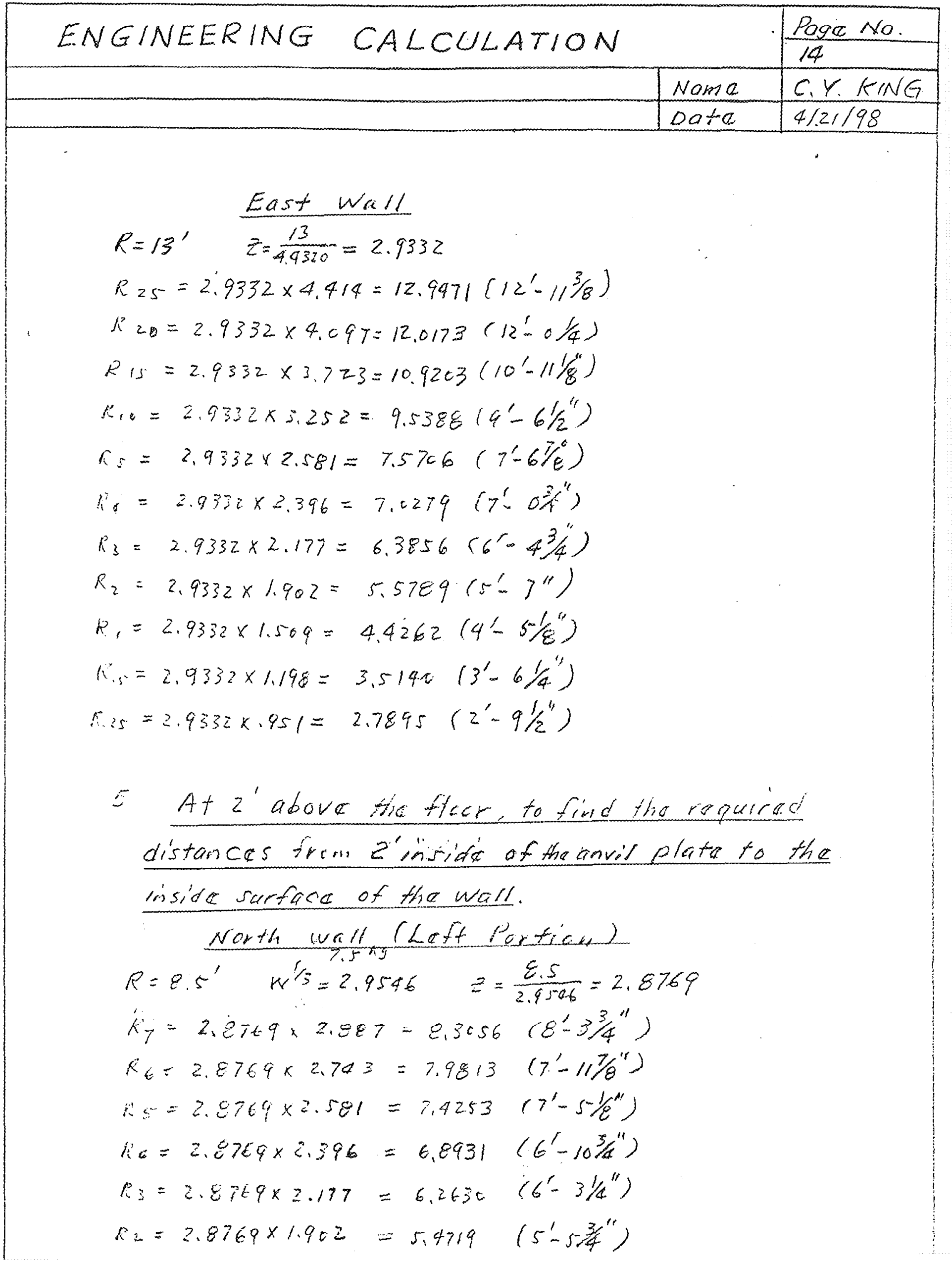




\section{ENGINEERING \\ CALCULATION}

Nama C.Y.KING

Date. 4/21/98

$$
\begin{aligned}
& \left.R_{1}=2.8769 \times 1.509=4.3412\left(4^{\prime}-4\right)^{\prime}\right) \\
& R_{.5}=2.8769 \times 1.198=3.4465\left(3^{\prime} .5 / 8\right) \\
& R_{.25}=2.8769 \times .951=2.7359\left(2^{\prime}-87 / 8\right)
\end{aligned}
$$

$R=\frac{\text { North wall (Right porticn) }}{W^{\prime}=2.9546 \quad z=\frac{19.5}{2.9546}=6.5999}$

$R_{7}=6.5994 \times 2.887=19.0539\left(19^{\prime}-0 \frac{3 \prime \prime}{4}\right)$

$R_{6}=6.5999 \times 2.743=18.1035\left(18^{\prime}-1 / 4 "\right)$

$R_{5}=6.5999 \times 2.581=17.0343\left(17^{\prime}-0 / 21\right)$

$R_{4}=6.5999 \times 2.396=15.8134\left(15^{\prime}-938^{\prime \prime}\right)$

$K_{3}=6.5999 \times 2.177=14.3680\left(19^{\prime}-4 \frac{1}{2}\right)^{\prime \prime}$

$R_{2}=6.5999 \times 1.902=12.5530\left(12^{\prime}-63^{\prime \prime}\right)$

$R_{1}=6.5999 \times 1.509=9.9592 \quad\left(9^{\prime}-11 \%^{\prime \prime}\right)$

$R_{15}=6.5999 \times 1.198=7.9067\left(7^{\prime}-11^{\prime \prime}\right)$

$R_{.25}=6.5999 \times .951=6.2765 \quad\left(6^{\prime}-3 \frac{3}{8}{ }^{\prime \prime}\right)$

$$
\begin{aligned}
& \frac{\text { West wall }}{W_{1 / 3}=2.9546} \\
& R=9.37^{\prime} \quad W^{13}=2.9546 \quad z=\frac{9.37}{2.9546}=3.1713 \\
& R_{7}=3.1713 \times 2.807=9.1555\left(9^{\prime}-178^{\prime \prime}\right) \\
& R_{6}=3.1713 \times 2.793=8.6989\left(8^{\prime}-8 /{ }^{\prime \prime}\right) \\
& n_{5}=3.1713 \times 2.581=8.1851\left(8^{\prime}-2 / / 4\right) \\
& k_{a}=3.1713 \times 2.396=7.5984\left(7^{\prime}-7 \%\right) \\
& n_{3}=3.173 \times 2.177=6.9039(6-1078) \\
& \kappa_{i}=3.1713 \times 1.902=6.4122\left(6^{\prime}-5^{\prime \prime}\right) \\
& x_{1}=3.1733 \times 1.509=5.0873\left(5^{\prime}-118_{8}^{\prime \prime}\right)
\end{aligned}
$$




\section{ENGINEERING CALCULATION \\ Poge No. \\ 16 \\ Noma \\ C.Y. KINE \\ Data \\ 4,198}

$$
\begin{aligned}
& R_{0.5}=3.1713 \times 1.198=3.7992\left(3^{\prime}-95 \%{ }^{*}\right) \\
& R_{0.25}=3.1713 \times .951=3.0159\left(3^{\prime}-0 \frac{1^{\prime \prime}}{4}\right)
\end{aligned}
$$

$$
\begin{aligned}
& \text { Socth wall } \\
& R=19.5^{\prime} \quad W^{1 / 3}=2.9546 \quad z=\frac{19.5}{2.9546}=6.5999 \\
& R_{7}=6.5994 \times 2.807=19.0539\left(14^{\prime}-03 / 4\right) \\
& R_{6}=6.5999 \times 2.743=18.1035\left(18^{\prime}-11^{\prime \prime}\right) \\
& R_{5}=6.5494 \times 2.581=17.0343\left(17^{\prime} .0 \% /{ }^{\prime \prime}\right) \\
& R_{A}=6.5999 \times 2.396=15.8134\left(15^{\prime}-97 / 8\right) \\
& R_{3}=6.5499 \times 0.179=14.3680\left(14^{\prime}-4 / 2 "\right) \\
& R_{2}=6.5999 \times 1.902=12,5530\left(12^{\prime} \cdot 6 \frac{3}{4}\right) \\
& k_{1}=6.5999 \times 1.509=9.9592(9-115 \% ") \\
& R_{6.5}=6.5449+1198=7.9067(7001) \\
& 0.25=6.5999 \times .954=6.2765(6)
\end{aligned}
$$

\section{East wall}

$R=13^{\prime} \quad W^{1 / 3}=2.9546 \quad w=\frac{13}{1.9546}=4.3999$

$$
\begin{aligned}
& R_{7}=4.3999 \times 2.889=12.7 \times\left(12-82^{\prime \prime}\right) \\
& R_{6}=4.5999 \times 2.745=12 . \\
& (12-078)
\end{aligned}
$$

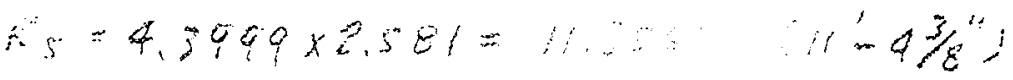

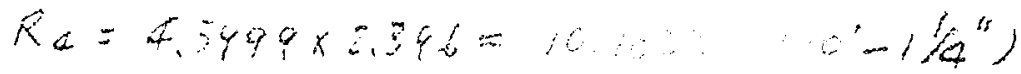$$
R_{3}=4.3999 \times 2.177=9.00 \quad\left(967^{\prime \prime}\right)
$$$$
R_{2}=4.3999 \times 1.902=0.080\left(8^{\prime}-4 / 2\right)
$$$$
R_{1}=4.3999 \times 1.509=6\left(20 \quad \sin \left(7_{4}^{\prime \prime}\right)\right.
$$

$R_{0.5}=4.3999 \times 1.198=0.09 \quad \therefore 330$

$R \times 15=4.3999 \times .951=4.2 \times 2101$ 


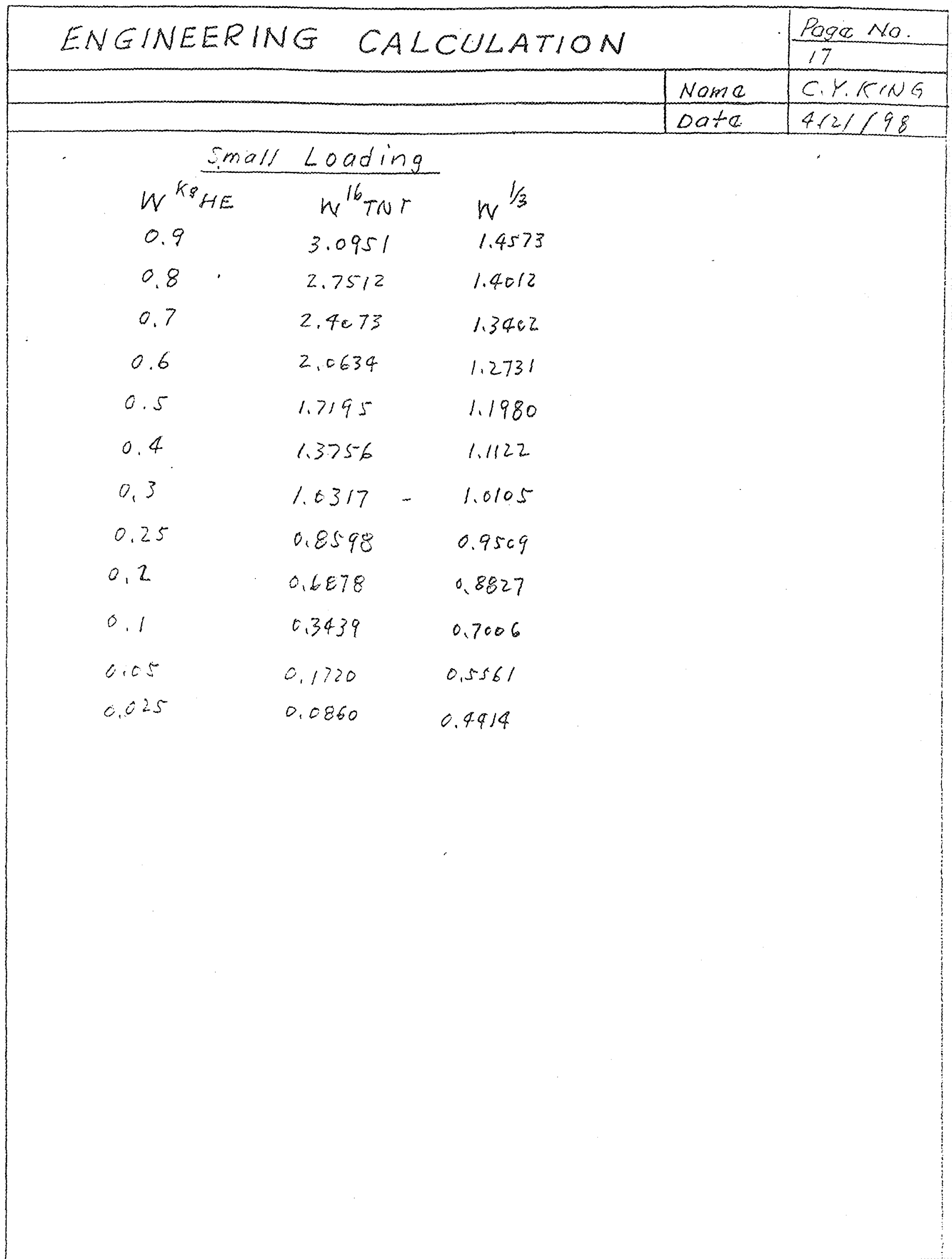




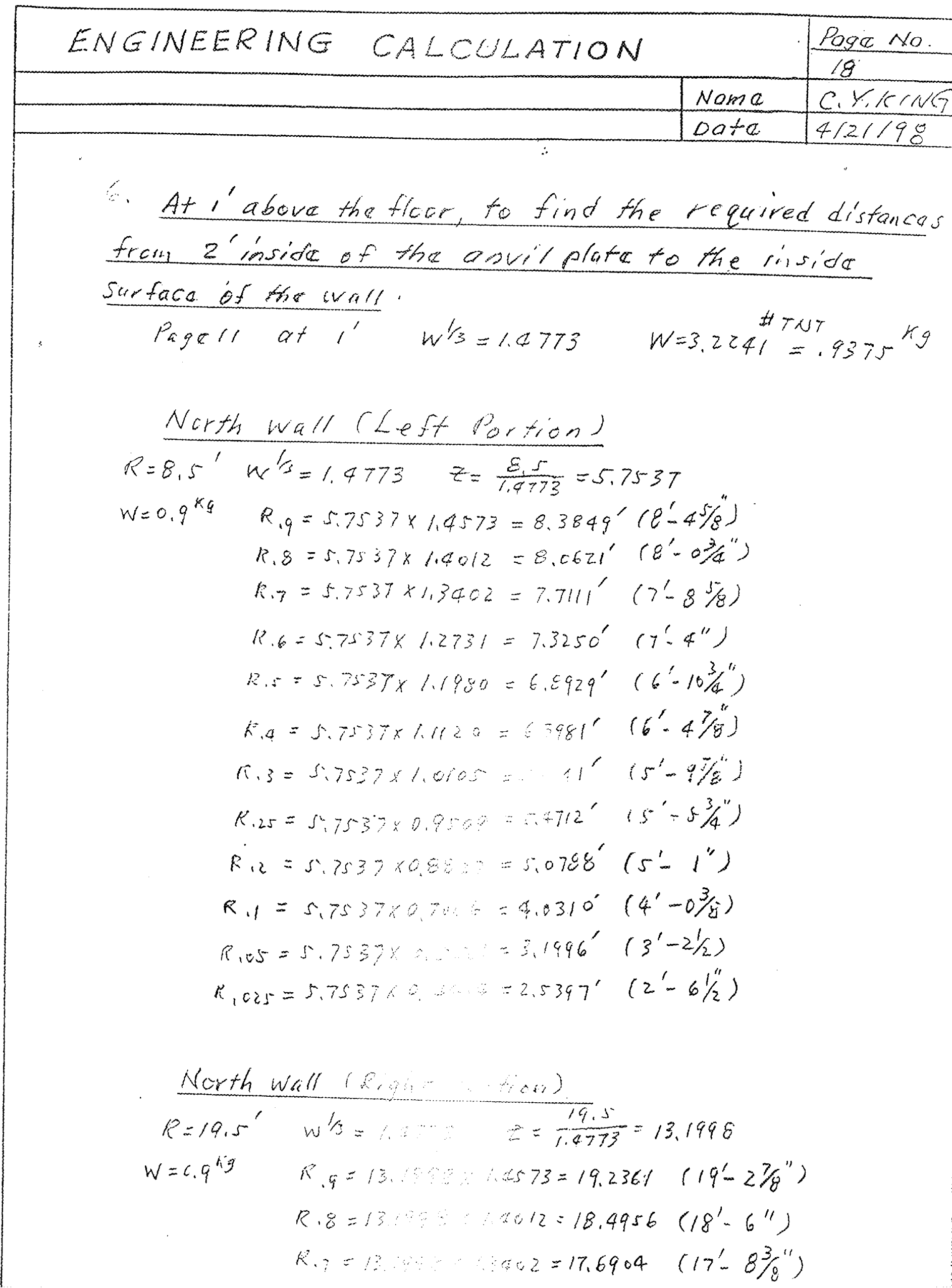




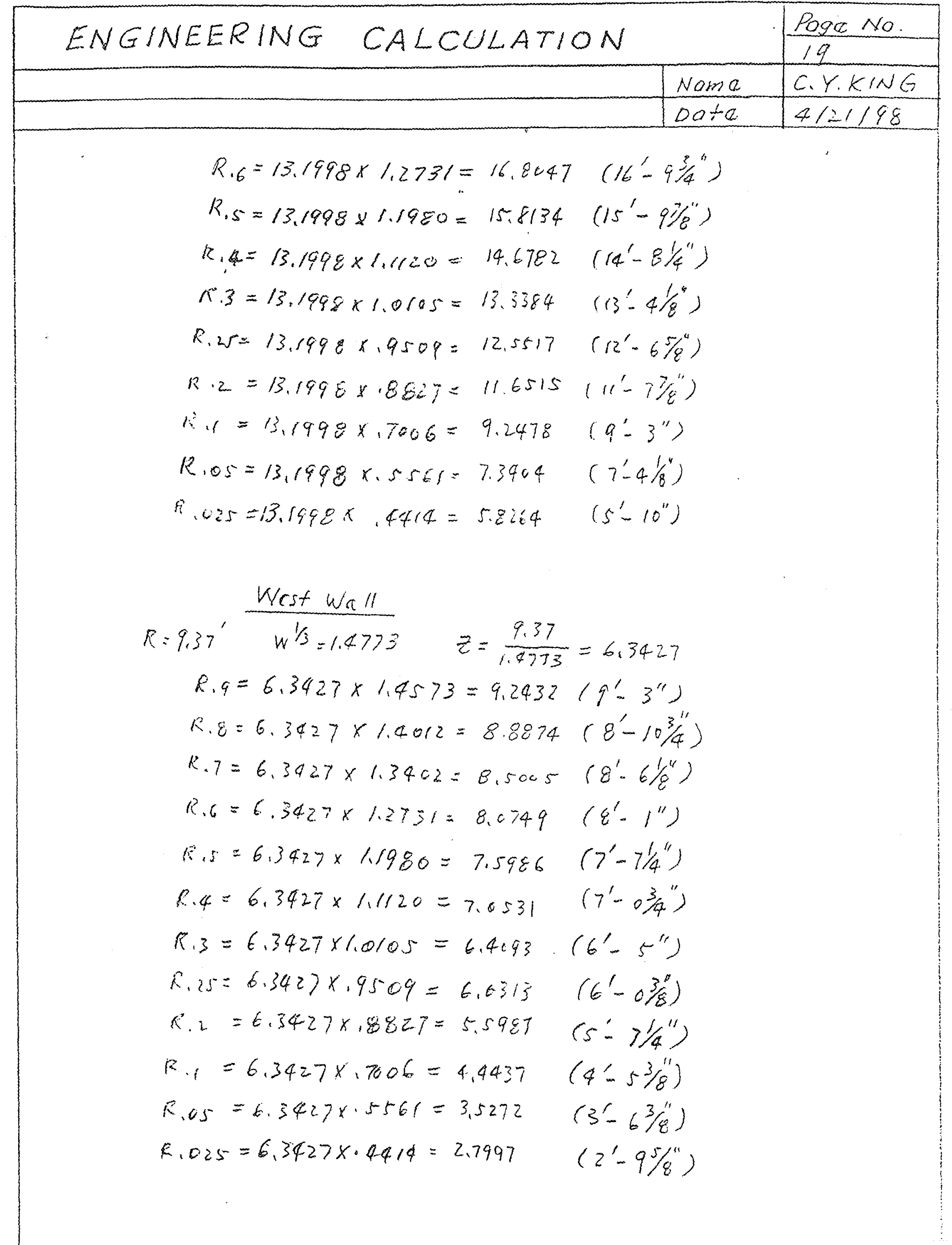




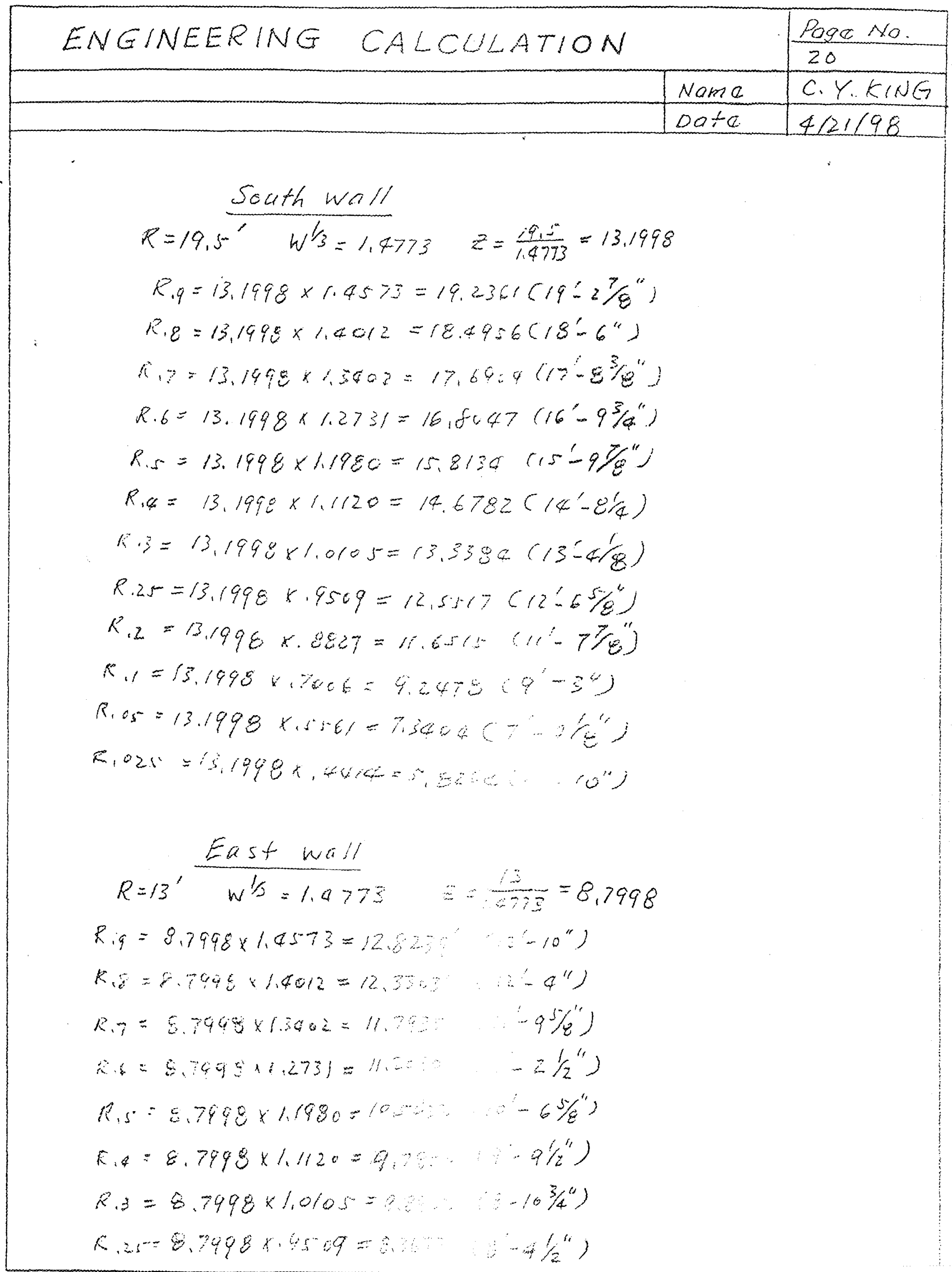




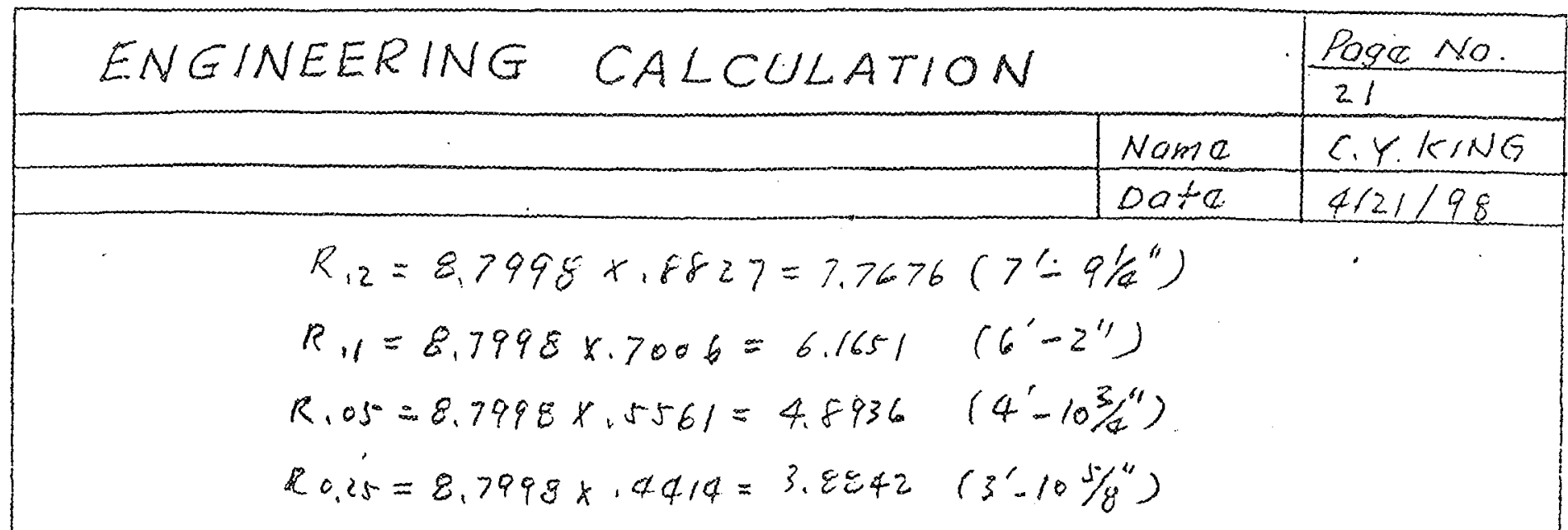

7. To determine standoff Distance.

For close -in region steep $z=1$

$$
\begin{aligned}
& z=\frac{R}{k^{6}}=1 \quad W=1^{K q} \mathrm{LHE}=3.434^{4} \mathrm{rNT} \quad \mathrm{r}^{1 / 3}=1.509^{16^{1 / 3}} \\
& \left.Z^{2}=\frac{R}{1.509}=1 \quad R=1.50 q^{\prime}(1)^{\prime \prime}\right)
\end{aligned}
$$

8. To find the distance from tho flor where the stress of the ceiling is $A^{k s i}$

concrete compression stress of floor $=12^{\text {its. }}$

$$
\begin{aligned}
& \text { coiteng }=4 \text { ks: } \\
& z_{\text {floor }}=\frac{4}{5.969}=.67 ? \\
& 2 \text { cailigig }=.677 \times \frac{12}{7}=2.031 \\
& \frac{l^{3}}{5.909}=2.031 \quad i^{3}=2.031 \times 5.909=12.03 \text { (frow (acting) } \\
& 30^{\prime}-12.03^{\prime}=17.47^{\prime} \text { (from floor) }
\end{aligned}
$$

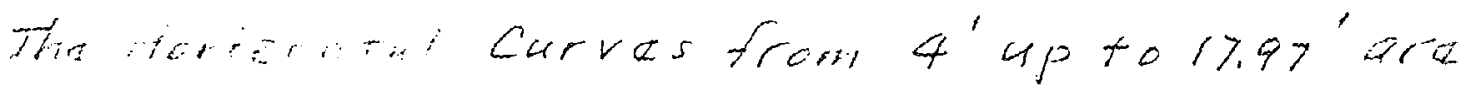
the same as $4^{\prime}$.

9. Above canara rani, hint $w=150$, to prevent damage of the Cam ara lens. 


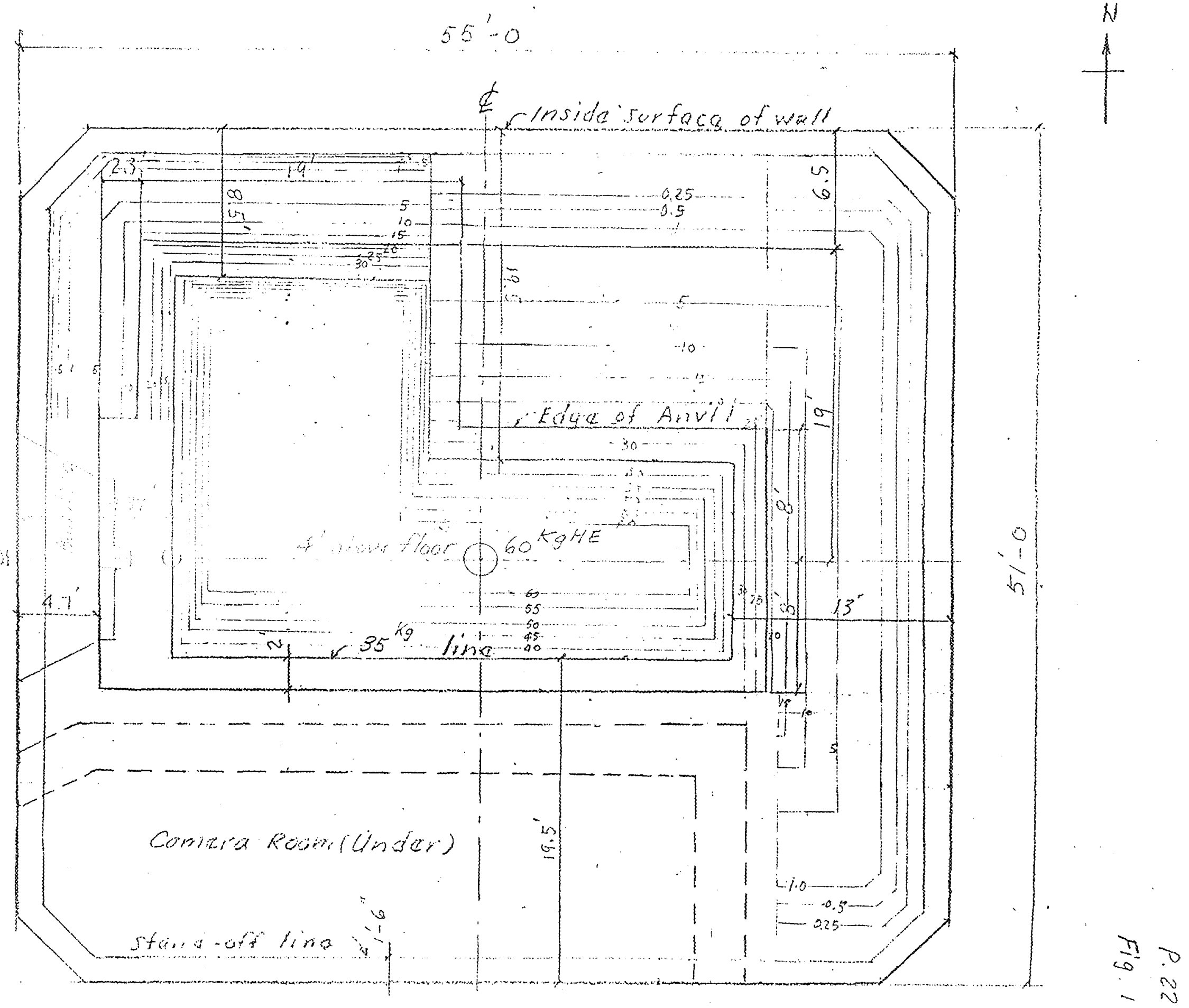




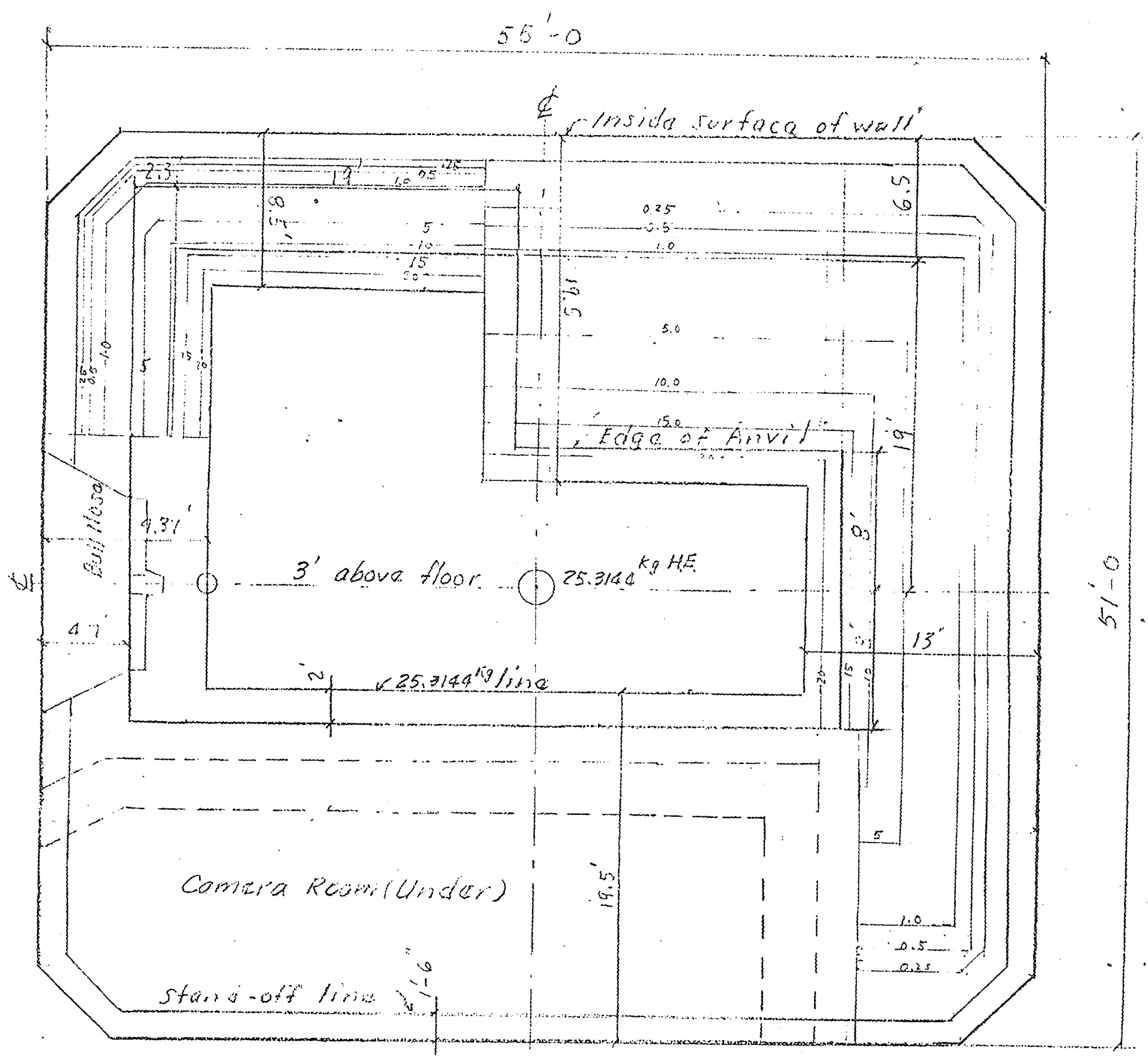




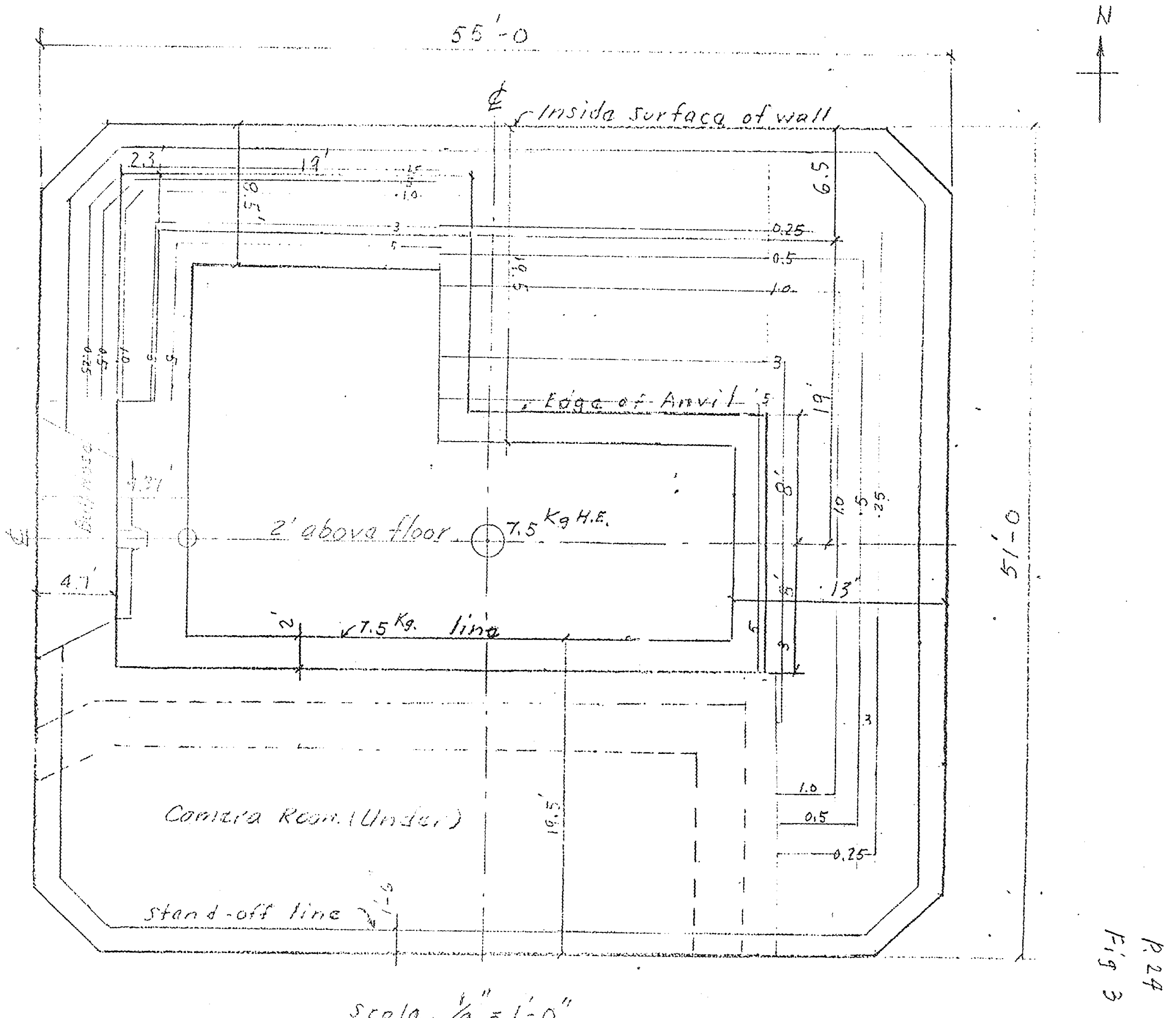




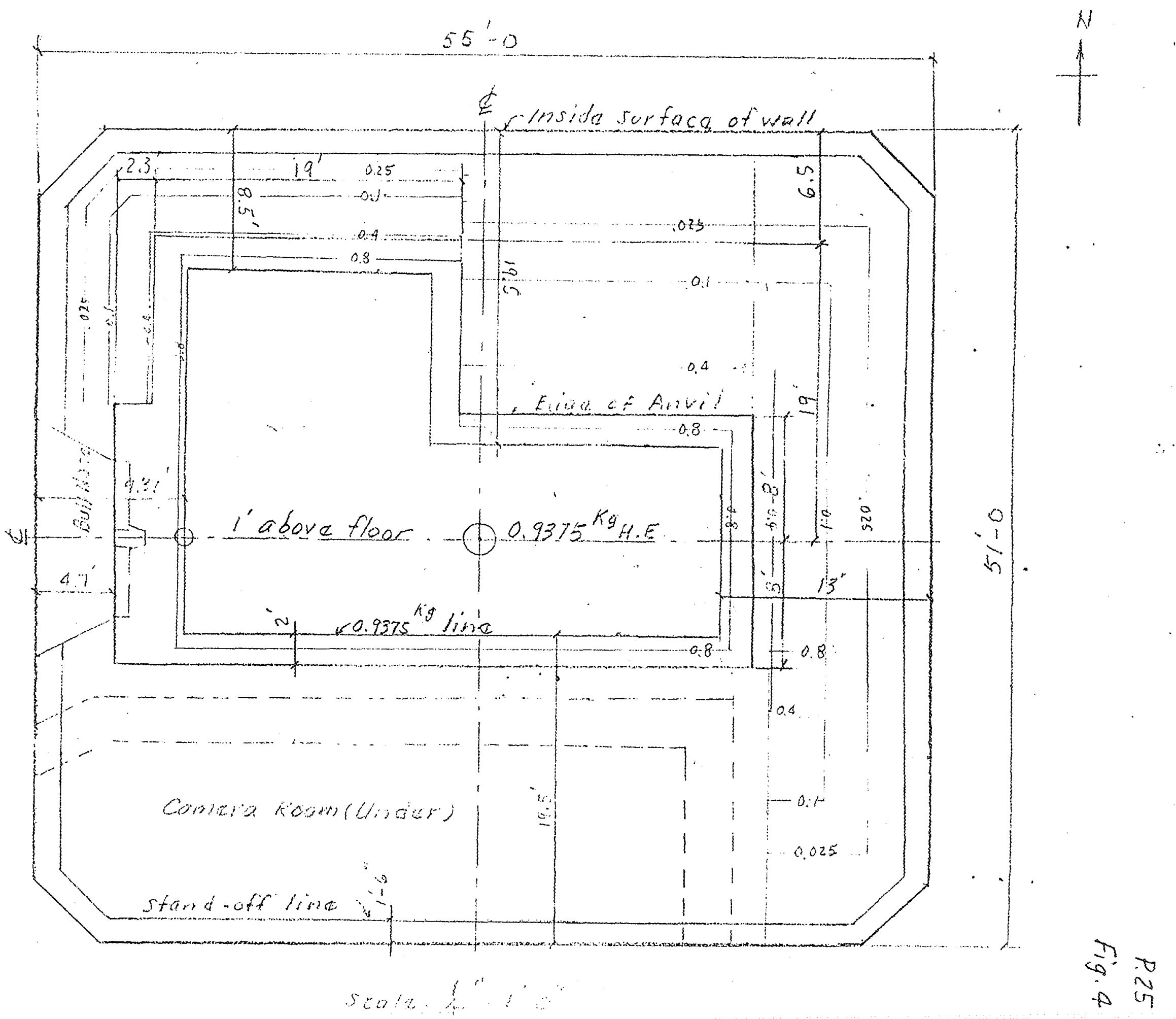




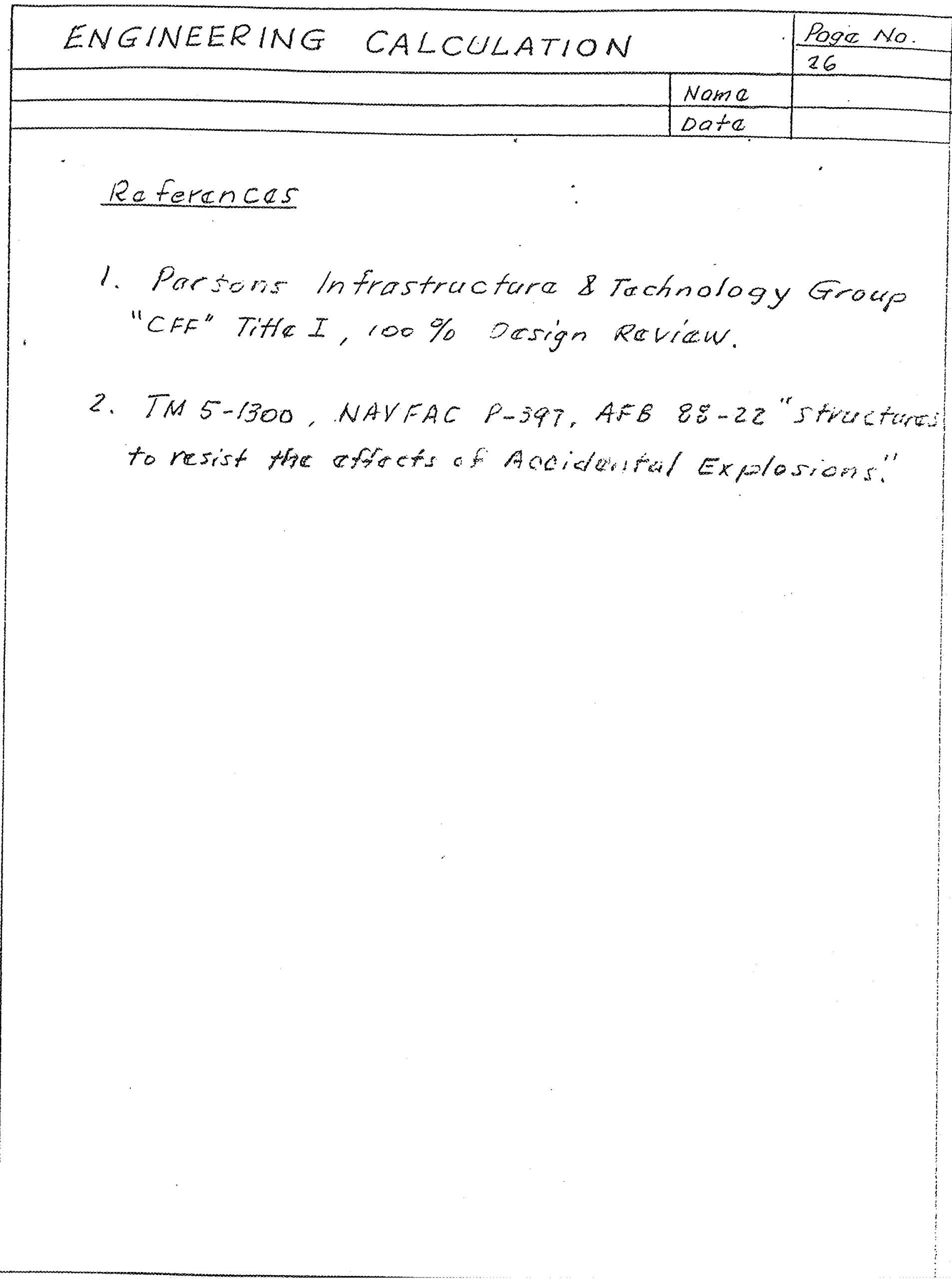

